\title{
Progressing Towards the Beloved through the Degrees of Witnessing
}

A significant part of al-Wāsițì's work on Sufism is concerned with a sequence of degrees of witnessing (sing. mashhad, pl. mashāhid) that the sālik must go through to attain friendship with God. These represent the advanced stages of his sulūk, built on the foundations we have set out in the previous chapter. In the current chapter, we will investigate in detail how al-Wāsiți envisioned this progress, which is supposed to lead to the apex of the spiritual journey. Besides studying what his writings tell us in that regard, we will again frequently point out where he was possibly influenced by the teachings he had come across during his physical journey. It is, above all, in this part of his doctrine where we will come across instances where he appears to have appropriated certain elements not only from the teachings of Ibn Taymiyya, but also from the Shādhiliyya. By uncovering such instances we can further see how his own formulation of Sufism can be contextualized against the background of his life's story studied in part 1 of the current book. Furthermore, given the fact that he wrote primarily for traditionalists, some of whom were from the Taymiyyan circle, there is particular merit in exploring the presence of Ibn Taymiyya's teachings in the topics we will study here, as this enables us to evaluate how al-Wāsițīs membership of the jamā'a possibly affected his own ideas as a scholar in his own right.

Below we will proceed on the basis of section 2 from the previous chapter by elaborating on the steps required to ascend to the stage wherein God's names and attributes are witnessed and how this process is defined. From there we will continue to study the sequence of the most important degrees of witnessing in chronological order, ending with the final degree where the end of alWāsițīs spiritual journey is reached. Before we start, however, we must briefly draw attention to what we may call al-Wāsițīs anthropology, that is, his understanding of human nature, as it is within the framework of this anthropology that the sequence of witnessing takes place.

A recurring element in al-Wāsițī's writings is the notion that a human being is made up of five dimensions (ațār , sing. tawr): the body (al-jism), the carnal 
soul (al-nafs), the intellect (al-'aql), the heart (al-qalb), and the spirit (al-rüh). He says:

A human being is one reality with an inward and an outward being. Its outward being is the body, and its inward being is likewise one thing. However, when it comes to that which is called the 'inner reality' (alhaqiqa al-bătiniyya), it has attributes that are called 'the heart,' 'the intellect,' 'the carnal soul,' and 'the spirit.' Now, that which moves within these different attributes is one thing, and this is the inward human being (alinsān al-bātin): With respect to love and affection, which bear a spiritual meaning (ma'na rūhāañ ), it is said that they are put in motion by one's spirit; with respect to one's fear, hope, reliance, determination, etc., which are practical attributes (șifät 'amalizya) by which it is possible to pursue [either] the afterlife or this world, it is said that they are put in motion by one's heart; with respect to one's concern for things and one's ability to distinguish between their truth and their falsehood, their good and their evil, it is said that they are put in motion by one's intellect and judgment $\left(r a^{\prime} y\right)$; with respect to one's carnal desire, such as the desire for food, clothing, intercourse, anger, superiority, honor, and pride, it is said that that this is put in motion by one's carnal soul. ${ }^{1}$

Thus, the body signifies one's outward physique (al-tarkìb al-qälibì), while the carnal soul, intellect, heart, and spirit are all distinct attributes of one's inward being. Each of these dimensions has its own characteristic motion: One moves outwardly with one's body parts, and inwardly - by emotions, thoughts, ideas, understanding, etc. - with the four attributes of the inner reality.

In order for the sālik to reach spiritual perfection, al-Wāsiți teaches that he is to subjugate each of these five dimensions in consecutive order. We can roughly describe this process as follows: First, he must traverse the body by observing the outward religious obligations and by guarding (ricaya) the seven body parts (his eyes, ears, tongue, stomach, private parts, hands, and legs). Second, he must traverse the carnal soul by conquering the faculty of worldly appetites, submit to God's decrees, and reject his own choice and self-direction. Third, he must traverse his intellect by becoming deeply acquainted with the Qur'an and the Sunna in order to learn the details of God's commands and prohibitions and understand them thoroughly. Fourth, he must traverse the

1 Al-Wāsițī, Qā'ida fìma'rifat al-naqș al-dākhil 'alā al-kamālmin al-'ārifín, wa-ma'rifat al-kamāl fi haqq man qāma bihi min al-wāșilīn ahl al-baqā' ba'd al-fanā' wa-al-ṣaḥ̂ ba'd al-sukr min maqūmāt al-muqarrabìn, p. 238. 
heart by realizing its stations (maqāmāt), such as fear of God, hope in God, love for God, trust in God, and so on. Fifth, he must traverse the spirit by establishing steadfastness (istiqāma) in all the former dimensions. According to alWāsițî, it is only by mastering each step in its own right that the sălik will be able to move forward to the next one, to finally reach perfection in the spirit. ${ }^{2}$

Interestingly, this sequence of human dimensions somewhat resembles what can be found in the very treatise of al-Shādhili that was attacked by Ibn Taymiyya in the refutation we referred to in the previous chapter. Although the Moroccan Sufi only names three dimensions instead of five, and refers to them as stations (manāzil), he likewise designates the spirit as the highest degree:

The first station in which the lover sets foot to ascend therefrom unto the Exalted is the carnal soul ( $n a f s$ ). He must occupy himself with controlling it and disciplining it until it results in intimate knowledge of it. When he knows it and has realized it, then it is there that divine lights shine upon him. The second station is the heart (qalb). Likewise, he must occupy himself with controlling it and [acquiring] knowledge of it. If he has completed this and there remains nothing more for him to gain from it, then he ascends unto the third station, which is the spirit $(r u \bar{u} h){ }^{3}$

In his refutation, Ibn Taymiyya cites this very passage from al-Shādhilī and comments on it as follows:

It is said in response: If [al-Shādhilī] means by the carnal soul, the heart, and the spirit that there is one [human] essence to which belongs a number of attributes, then that is correct. As for mentioning that which is called the carnal soul before the heart, and that which is called the heart before the spirit, then this is a matter of a convention of terms ( $\mathrm{amr}$ isțilāhi $\bar{l}$ and there is no basis for it in the words of God and His Messenger. ${ }^{4}$

In fact, he goes on to argue, the nușuṣ actually prove that there is no one definition to these terms that would necessarily place one above the other. The carnal soul, the heart, and the spirit are all described by righteousness in some

2 Al-Wāsițī, Madkhal ahl al-figh, pp. 46-48; Qã̃ida fi habs al-nafs wa-al-'ukūf 'alā al-hamm,

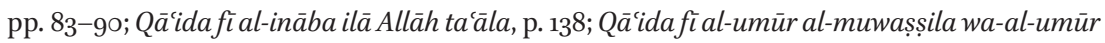
al-qāțía, pp. 224-226; Qāंida fì márifat al-naqș, pp. 230-233; Qāंida fì al-tajrīd, pp. 252-253;

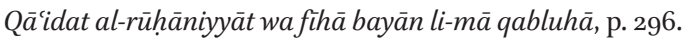

3 Ibn al-Ṣabbāgh, Durrat al-asrār, p. 134.

4 Ibn Taymiyya, al-Radd 'alā al-Shädhilī, p. 127. 
instances, and by corruption in others. Therefore, he concludes, "[t]his sequence, if it is said to be correct, is peculiar to an appointed convention of terms; it is not a scientific matter $\left(a m r^{\prime}\right.$ ' $\left.i m \bar{\imath}\right)$, nor is it generally applicable to every sālik." In other words, while he does not deny that these attributes exist within each human being, he sees no hard proof for the claim that the spirit signifies their highest degree, or that there is a particular sequence to them that applies to every believer on the spiritual path.

However, the importance of the five dimensions distinguished by al-Wāsiți lay exactly in his conviction that there is a fixed sequence to them. Here he clearly disagrees with the teachings of Ibn Taymiyya. Like al-Shādhilī, he believed that one reaches the spirit only after traversing the carnal soul and the heart. In addition, he held that it is specifically within the heart and the spirit that the required sequence of degrees of witnessing takes place, with the spirit being the locus of the most distinguished and complete of them. We can thus conclude that an essential part of his doctrine on witnessing was directly at variance with the opinion of his Hanbali master. How exactly he envisioned this doctrine we may now begin to unravel.

\section{$2 \quad$ Putting Márifa into Practice}

Picking up where we left off at the end of the second section of chapter 4, we will start by examining how the remainder of al-Wāsițīs sulūk builds on the theological foundations of ma'rifa we have thus far been able to distinguish. As we have seen, after adopting a correct understanding of the divine names and attributes, the sālik's subsequent step is to recite God's Speech, the Qur'an, and reflect on it as if hearing it directly from its Speaker. By doing so, al-Wāsitịi held that the sālik should become open to the revelation's tajalliyyāt: God's Selfmanifestations through these names and attributes.

From here al-Wāsiți quickly turns theological theory into practice, as the sălik is said to become truly acquainted with God exactly as He describes Himself in His revelation - the Qur'an, but also the Sunna - or rather, as He manifests Himself therein:

Described by the divine attributes (al-mawșüf), [God] manifests to the hearts [of the knowers] through [His] speech: Sometimes with His promise, sometimes with His threat, sometimes with His force, sometimes with His kindness, sometimes with His mercy, and sometimes with His

5 Ibid. p. 128. 
intimidation and His assault's severity; the cups circle around them, and the drinks that are required to love and glorify [Him] became manifold before them due to the variety of [His] attributes - for every attribute requires a certain taste $\left(\right.$ dhaw $\left.^{a n}\right)$, and every taste requires a certain love $\left(h u b b^{a n}\right)$. If but one attribute can enrapture the lover and take his heart, then what is one to think of the attributes when they all manifest simultaneously to the heart and their illumination is lit up inside the spirit? 6

This passage requires some elaboration. Essentially, it sums up the process of becoming a complete 'ârif, or 'knower,' of God. Again, as previously explained regarding the term ma'rifa, this is not directly a matter of receiving divine knowledge through some spiritual unveiling (commonly referred to in Sufism as ' $k a s h f$ '). Simply put, our Iraqi Sufi holds that anyone who acquires ma'rifa of some aspect of God's Being through His names and attributes becomes a knower of Him by that particular knowledge. ${ }^{7}$ There are, however, degrees to being an 'ärif; the more complete the sālik's knowledge of God, the more perfect a knower he is. The final line of the above quote alludes to this and is meant as a reference to the state wherein all attributes are witnessed at once, a subject we will get to in the final section of this chapter.

Another observation we have made before, which is also hinted at in our quote, is that each name and attribute of God can be seen as a piece of the puzzle of complete márifa; or as al-Wāsiți puts it elsewhere, each of them is an 'arch' (țāqa) or a 'door' (bāb) through which one may acquire the entirety of knowledge of God. In his view, not only do they all represent a particular aspect of God's Being, but like a puzzle, each is directly connected with other specific names and attributes. If, for example, the knower knows God by His name 'the All-Knowing' (al-'alim), then this name requires that God also possesses the attribute of life; if the knower knows that God directs His creation, which is the attribute of tadbir , then this requires that God also possesses the attributes of knowledge, volition, strength, wisdom, provision, mercy, power, and others of this kind. ${ }^{8}$ Names and attributes are thus interconnected, and it is up to the sālik to reflect and meditate on them to uncover how the pieces of the puzzle come together. The overarching purpose of this part of sulük is to thereby become acquainted with every single aspect of God's Being, because,

6 Al-Wāsițī, al-Sirr al-mașūn, p. 58; a somewhat similar explanation is given in Umdat al-țullāb, p. 206, and also in Qā'ida fì al-umūr al-muwașșila, p. 219.

7 Al-Wāsițī, Talqūh al-asrār, pp. 49-50.

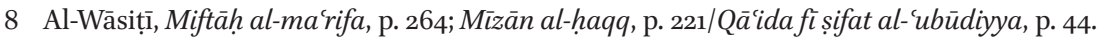


al-Wāsiți argues, servitude of God remains incomplete as long as it is not done with all His names and attributes and the magnificence of His essence. ${ }^{9}$

As for the 'taste' and 'love' required for each attribute, this pertains to the diversity that is inherent to ma'rifa. Even though God is one in His essence, His attributes are manifold. Hence, there are different meanings ( $m a a^{c} a n^{i n}$ mukhtalifa) that all subsist in one God. Because each name or attribute has its own specific meaning (ma'nā khāṣs), they all have a particular taste (dhawq khāṣs ) by which the knower becomes acquainted with God. ${ }^{10}$ According to al-Wāsițī, when the realities (haqäiq) of the names and attributes are unveiled and the knower discovers their tastes, that is when he will actually witness them. ${ }^{11}$ Each attribute then becomes a way to love God, for, as he explains, knowledge of God requires love. While it is possible that a human being knows something that he does not love, it is inconceivable that he knows something about God except that it is combined with love for Him. ${ }^{12}$ At this stage the sălik is therefore described by al-Wāsiți as "al-muhibb al-ārif al-dhä'iq," which we may render as the lover of God who knows Him by His names and attributes and has experienced their tastes. ${ }^{13}$

While these observations do reflect the essentials of the way al-Wāsitị sought to apply ma'rifa, we are still left with a rather ambiguous narrative. It fails to explain how exactly one is supposed to uncover the realities of the names and attributes to eventually acquire their taste and witness them, and it gives no clarification at all as to what these experiences actually signify. Therefore, the current section will be devoted to filling these gaps by delving deeper into al-Wāsițî̀s teachings on the divine names and attributes.

\subsection{Servitude through the Divine Names and Attributes}

When studying what al-Wāsițì's writings say regarding the practical application of the sālik's knowledge of God's Self-manifestations in the nuṣuṣs, it quickly becomes apparent that he relied heavily on Shādhili teachings for this aspect of his doctrine. Like the early Shädhili sources we studied in chapter 2, alWāsițī puts much focus on what we identified as an essential dichotomy of 'ubüdiyya and rubübiyya: mankind's absolute state of servitude as opposed to God's absolute lordship over all things. We may recall the following statement attributed to al-Shādhilī: "Sufism is to train the carnal soul to be in accordance

9 Al-Wāsițī, Qā'ida fì márifat al-naqș al-dākhil 'alā al-kamāl min al-ārifín, p. 230.

10 Al-Wāsițī, Miftāh al-márifa, p. 264; Mìzān al-ḥaqq, p. 221/Q̄ácida fì șifat al-ubūdìyya, p. 44; Qāंida fima'rifat al-naqș, p. 230.

11 Al-Wāsițī, Miftāḥ al-márifa, p. 264.

12 Al-Wāsițī, Mìzān al-ḥaqq, pp. 220-221/Qā'ida fì șifat al-ubūdiyya, p. 43.

13 Al-Wāsițī, Miftāḥ al-márifa, p. 264. 
with servitude, and to return it to the principles of lordship (ahkām alrubübiyya)." ${ }^{14}$ We can find al-Wāsiți stating in the same vein that "the servant's most noble state is to display the attributes of servitude and be satisfied with the principles of lordship (al-irtid ă' li-ahkām al-rubūbiyya)." ${ }^{15}$ As we will now see, Shādhili teachings permeate practically all of his further ideas on the practical use of the divine names and attributes in Sufism.

This is first apparent in what he regards as the inevitable realization that the attributes of God and the attributes of His creatures are in all respects opposites. Human beings have their very own attributes inherent to their state of 'ubüdiyya, and God has His very own attributes inherent to His rubübiyya. AlWāsiți cites a report about the Prophet David in that regard, according to which

God (T) said to David ('A): "O David, you must know Me and you must know yourself." He replied: "O Lord, I know myself by [the attributes of] weakness, feebleness, and finiteness, and I know You [by the attributes of] power, strength, and infinity!" Then God (T) said: "O David, now you know Me!" - or something similar to that. The servant must thus attend to his own attributes, know himself by them, and not overstep them lest he be counted among those who are ignorant! ${ }^{16}$

In a precept on the divine attributes he elaborates further on this notion where he advises the sālik that

if you desire to realize servitude and submit to the principles of lordship, then sit on the carpet of truthfulness (bisāt al-șidq) in reflection on your Master and what He alone possesses of [lordship] in the magnificence of His Being and the holiness of His majesty, while reflecting also on your finite attributes befitting of you. Then single out your Master by what is due to Him alone of the magnificence of His Being and the holiness of His attributes, and realize your own attributes and stick to them so that you do not overstep their limits. Reflect on [God's] attributes, then on your own attributes while reflecting on Him by them. ${ }^{17}$

It is surely no coincidence that what al-Wāsiți describes as the effort to realize what is due to God and what is due to His servants, in terms of attributes, was

\footnotetext{
14 Ibn al-Ṣabbāgh, Durrat al-asrār, p. 9o.

15 Al-Wāsițī, Qã ida fì șifat al-ubūdiyya, p. 41.

16 Al-Wāsițī, Mìzān al-haqqq, pp. 219-22o/Qã̄ida fì șifat al-ubūdiyya, p. 42.

17 Al-Wāsițī, Qā'ida fíal-șifăt, p. 318.
} 
likewise referred to as 'sitting on the carpet of truthfulness' by al-Shādhilī, as we have noted in chapter $2 .{ }^{18}$ We will take a closer look at what this requires of the sālik, and what reflecting on one's own attributes while reflecting on God exactly means.

When it comes to what is due to God, al-Wāsiți considers it an obligation to know the perfection of all the different categories of divine names and attributes that can be found in the nușūs. God is described in the revelation with active attributes (sifät filiyya), which pertain to His involvement in His creation, such as 'the Creator' (al-khallāq), 'the Bestower' (al-wahhāb), 'the Provider' (al-razzāq), 'the Opener' (al-fattăh), and so on. He is also described with attributes connected to circumstances (sifät hâaliyya) in the sense that they only manifest at particular times, such as when He will order people to enter the fire on the Day of Judgment, or when He descends to the heavenly layer that is nearest to earth in the last third of the night. He is also described with attributes that belong to His essence (șifāt dhātiyya), which are inherent to Him in pre-eternity and post-eternity, such as life (hayāt), knowledge ('ilm), creative power (qudra), hearing (sam), sight (bașr), will (iräda), majesty (jalāl), beauty (jamāl), holiness (quds), and perfection (kamāl); to this category also belong the names of His essence, such as 'Allāh,' 'He' (huwa), and 'You' (anta).19

After careful reflection on God's perfect names and attributes, al-Wāsiți teaches that the sālik must realize his own imperfect human names and attributes, seek out those which are best suited for him in his humanness, and stick to them. He recognizes two categories in that regard:

The servant has exalted names and vile names. As for his exalted names, God ('AJ) has described him by them where He (T) says: "Those who repent (al-tāỉbūn), those who serve (al-'äbidūn), those who praise (alhămidūn), those who journey (al-säihüun) ..." [Q. 9:112] - until the end [of the verse] - and in His statement (T): "Men and women who have surrendered (al-muslimin wa-al-muslimāt), men and women who believe (al-mu'minin wa-al-mu'mināt), men [and women] who obey (al-qānitīn [wa-al-qānițāt]) ..." [Q. 33:35] - until the end [of the verse]. Examples of his vile names include: 'the disobedient' (al-'āșì), 'the sinner' (al-mudhnib), 'the wrongdoer' (al-zālim), and so on. ${ }^{20}$

18 As quoted in chapter 2 from Ibn al-Ṣabbāgh's Durrat al-asrār, p. 72.

19 Al-Wāsițī, Qã̄ida fì al-ṣifāt, pp. 319-320.

20 Ibid. p. $3^{20}$. 
Again, we have in this divide of vile and exalted human names a clear example of reliance on Shādhilī teachings. In fact, it seems that al-Wāsițī may have plagiarized the above-quoted words from al-Shādhilī himself, to whom the following is attributed:

The servant has vile names and exalted names. As for his exalted names, God has described him by them in His statement: "those who repent, those who serve, those who praise ..." [Q. 9:112] - until the end [of the verse] - and in His statement: "Men and women who have surrendered ..." [Q. 33:35] - until the end [of the verse]. His vile names are [also] known, such as 'the disobedient,' 'the sinner,' 'the dissolute, 'the wrongdoer,' and so on. ${ }^{21}$

Furthermore, like al-Shādhilī, our Iraqi Sufi maintains that those who uphold servitude of God may blot out their vile names with their exalted names. ${ }^{22}$ For example, the name 'sinner' may be replaced with the name 'penitent,' the name 'disobedient' with the name 'obedient,' and the name 'wrongdoer' with the name 'just.'23

For al-Wāsițī, it is through knowledge of what is due to God and what is due to the servant in terms of names and attributes that God may truly be served. In an earlier quote it was suggested that in order to uncover the realities of the divine attributes, the sălik must reflect on them and their relation to his own attributes. Our Iraqi Sufi taught that this reflection reveals what every single name or attribute of God requires, as each of them has its own particular form of servitude:

Every name or attribute with its specific meaning requires a specific servitude from the servants who know their Lord by it. If someone knows his Lord $(\mathrm{T})$ by something of His names, attributes, or actions, then an indication and a proof of the soundness of his ma'rifa of Him is that he serves God (T) - Whom he knows by that particular name or attribute - with a servitude that corresponds to what the effect imposed by [this] ma'rifa requires. ${ }^{24}$

\footnotetext{
$21 \quad$ Ibn al-Ṣabbāgh, Durrat al-asrār, p. 132.

22 Ibid. Again, the passage in question has been quoted in chapter 2.

23 Al-Wāsițī, Qā'ida fí al-ṣifāt, pp. 320-321.

24 Al-Wāsițī, Mìzān al-haqqq, p. 221/Q̄àida fis șifat al-ubūdiyya, p. 45.
} 
Thus, the act of servitude that belongs to a particular name or attribute of God manifests by the realization of a corresponding name or attribute that exists in the servant. This is what al-Wāsiți refers to as upholding 'the principles of the divine names and attributes' (ahkām al-asmāa wa-al-siffāt), which is to serve each of them by fulfilling the requirements of their respective meanings; in other words, it is to serve God by means of one's ma'rifa of Him. ${ }^{25}$

We may better understand what this means by looking at several examples al-Wāsițī gives in his writings. These will simultaneously show that he relied once more on an approach that also appears to have been taught amidst the early Shādhiliyya. If, for instance, the sālik reflects on God's name 'the SelfSufficient' (al-ghani), he should come to the conclusion that this attribute requires that God is served by one's being in need of Him. Hence, an indication that the servant knows God by this particular attribute is that his heart practices the true meaning of neediness (haqiquat al-iftiqār). This principle holds true for all the names and attributes: Ma'rifa of the attribute of 'power' (qudra) requires its own corresponding servitude, which is the human attribute of incapacity ('ajz). Likewise, ma'rifa of the attribute of 'might' ('izza) requires servitude with the human attribute of lowliness towards God's might and humility towards His rulings. And ma'rifa of the attribute of 'strength' (quwwa) requires servitude with the human attribute of weakness, which manifests when the human being accepts his weak nature by seeking help from God, the Strong $(a l-q a w \bar{y}) .{ }^{26}$ We have seen in chapter 2 that these exact same examples are also related from al-Shādhilī as the effects of 'sitting on the carpet of truthfulness. ${ }^{27}$

It is thus apparent that al-Wāsițī's method to uncover the realities of the divine names and attributes contains some unmistakably Shādhilī elements. It is relevant to add here that I have not been able to find evident traces of a similar practical use of ma'rifa in the works of Ibn Taymiyya. This would mean that, despite his critical attitude towards the Shādhiliyya, al-Wāsiți probably continued to rely on some of their teachings that he considered to be in harmony with his traditionalist vision of Sufism. We have previously noted that his method of becoming acquainted with God by studying the nuṣuṣ is clearly

25 Al-Wāsițī, Qā'ida fì márifat al-naqș, pp. 230-231; Qā'ida ya'rifu al-'abd fihà nașïbahu min rabbihi wa-bu'dahu min ḥuzüz nafsihi, p. 2o9; Talqüh al-asrār, p. 64.

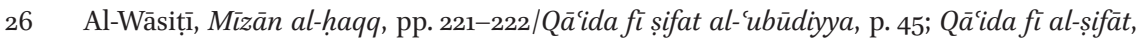
p. 318 .

27 As we see here, the examples al-Wāsiți gives were also treated in the paragraph on the divine attributes in Shādhilī doctrine in chapter 2, wherein we quoted from Ibn alṢabbāgh, Durrat al-asrār, p. 72. Al-Wāsiți gives more examples of the forms of servitude connected to specific attributes of God in: Q āंida ya'rifu al-'abd fìhā nașïbahu, pp. 210-211. 
rooted in the traditionalist principle of knowing God "as He describes Himself," which undoubtedly would have resonated well with his traditionalist pupils in Damascus. One can imagine, then, that the sober Shādhili method that utilizes ma'rifa by putting one's human attributes in the service of God's attributes would likewise have resonated well among them due to its emphasis on the absolute distinction between creation and Creator.

\subsection{The Heart as the Locus of Witnessing}

After having described the process of uncovering the reality of the divine names and attributes by fulfilling their practices of servitude, al-Wāsiți finally engages with them on the level of personal experience. This is where the academic, theological exercise we have thus far treated shifts into what al-Wāsiți refers to as the 'taste' (dhawq) or 'witnessing' (mashhad) of the names and attributes, Sufi terms that convey the possibility of a certain perception thereof. Below we will investigate how he describes this process in his writings. We will devote special attention to the theological problem he clearly recognized in using a language that runs the risk of being taken as a perception of God by the sensory faculties. As we will see, a significant part of his explanation of tasting and witnessing is therefore devoted to justifying a this-worldly perception of God.

Before we begin, it is necessary to note that while we have come across the term dhawq several times already, in relation to the topic at hand it is specifically connected to the mashhad, or witnessing, of a divine name or attribute. Because al-Wāsițī never clearly defines either term, the way in which they relate to one another sometimes appears vague. A close comparison reveals that they are without a doubt related and at times synonymous. That they do not signify separate steps is, above all, clear in one of his letters, wherein he states that the 'taster' of a divine attribute is someone who tastes the mashhad of that attribute. ${ }^{28}$

But how did he understand this experience? In the same letter he explains that it results from having traversed all the steps in sulük thus far described, which causes 'something' (shay') to become established in the heart:

This ['something'] is how the knower tastes the reality of the existence of a divine attribute, free from modality and likeness [to the attributes of creatures]. God (T) says: "His is the most exalted similitude (al-mathal $\left.a l-a^{\imath} l \bar{a}\right)$ in the heavens and the earth" [Q. 16:60/30:27] - and it is related in

28 Al-Wāsițī, Risālatuhu ilā al-shaykh al-Maghribī, p. 111, where he states: “... al-shuhūd alladhì dhāqahu al-dhā̉iq ..." 
the hadīth: "Exalted is Your greatness (tacălā jadduka)." Thus, His (ST) is the most exalted similitude in the heavens and the earth and in the hearts of the believers. This similitude has no similitude that resembles it, and it is this similitude that the knowers find in their hearts. ${ }^{29}$

Thus, the 'something' that becomes established in the heart of the knower is 'the most exalted similitude' - most exalted because it belongs to God alone. According to al-Wāsițì's interpretation, it is this similitude that is meant by the word 'greatness' in the quoted supplication of the Prophet: "Exalted is Your greatness." ${ }^{30}$ He holds that whatever is perceived of God's names and attributes in one's human capacity must necessarily be a similitude - although this similitude is exalted above, and thus in reality incomparable to, all other similitudes. This is so, he explains, because human beings, jinn, and angels cannot serve what is unknown, let alone witness it: ${ }^{31}$

The servant must not feel repelled by [the most exalted similitude], for he will only know God by it, only invoke Him by it, and only love Him by it. If it was not for [this similitude], [God] would neither be known nor served. It is thus inevitable that the similitude of the One to Whom nothing is similar is held in the hearts. ${ }^{32}$

In his treatise on the divine attributes, al-Wāsiți adds that, because it is by this similitude that God is served, many ignorant people err by worshipping the similitude rather than its possessor, God. ${ }^{33}$

As previously noted, he was fully aware that this approach to the process of spiritual witnessing may mistakenly be taken as an attempt to propagate an anthropomorphic conception of God. This would, of course, be at complete variance with the creed he himself advocated, according to which God has no modality and is in no way similar to His creation. In his writings, he claims to find the solution to what seems to be an inherent contradiction in the very concept of 'the most exalted similitude':

29 Al-Wāsițī, Miftāḥ al-márifa, p. 264.

30 Al-Wāsițī, Risālatuhu ilā al-shaykh al-Maghribū, p. 111. For the hadīth in question, see for instance: Muslim, al-Musnad al-șaḥ̄h, vol. 1, p. 299.

31 Al-Wāsițī, Qā'ida fíal-mathal al-a'́lā, p. 290.

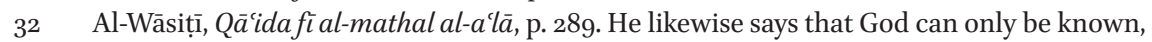
served, loved, feared, etc. by the most exalted similitude in his: Risālatuhu ilā al-shaykh al-Maghrib̄̄, p. 111; Qā'ida fì maqāșid al-sālikìn, p. 68. 
The sălik should know that when he directs himself [towards God], something may become established in his heart that he witnesses above the Throne. He must not feel repelled by it, because he may say: "this that I am witnessing is a body." While everything that reveals itself to your mind is either a body (jism) or an accident ('arad), it is known that imagination cannot give form to the reality of God (ST), understanding cannot encompass Him, and neither heart nor spirit can comprehend Him. However, it may be that similitudes (mithāl) become established [in the heart] upon being directed towards [God's] magnificence ('azama). These similitudes are a medium (wäsit a) between the One Who has no similarity and those who do. ${ }^{34}$

What he tells us here in a way resembles his argumentation for the affirmation of aboveness as the direction (qibla) that the servant's heart should turn towards when worshipping God. Besides the evidence he presented from the nușūs, this affirmation relied on mankind's innate nature to be in need of direction due to our inability to conceive the reality of directionlessness. In the same manner, our knowledge of God's names and attributes inevitably fixes 'something' in the heart that may be an image (khayāl), even if we profess with absolute confidence that God is nothing like His creation. ${ }^{35}$ This is due to our human inability to comprehend what cannot be grasped in our state of createdness and temporality.

Al-Wāsițîs argumentation here also leans on the essential distinction between human beings and God. Since mankind is essentially imperfect and God essentially perfect, it is impossible that they share qualities. The similitude of God that we see in our hearts through one of His names or attributes is therefore in accordance with our own imperfection and, as such, not even a reflection of His true reality:

Know that that there are two sides to this similitude that becomes established in the hearts when being directed [towards God] and supplicating [Him]: a side associated with the servant, and a side associated with the direction of [God's] magnificence. It is not said that [God's similitude] is not God, nor is it said that it is Him. Rather, it is a light in accordance with the servant's mirror, his createdness, and his feebleness. ${ }^{36}$ a'lā", wa-qawl al-nabì (Ș): "tabārak ismuka wa-ta'ālā jadduka", p. 289.

35 Al-Wāsițī, Miftāḥ al-ma'rifa, p. 264.

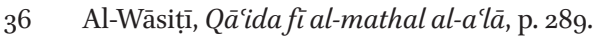


This is very much in line with al-Wāsițī's traditionalist cosmology studied in chapter 4, according to which God's essence exists outside the created realm, completely separate $(b \bar{a}$ in $)$ from His creation. Although not explicitly stated, this understanding of God's existence also forms the basis for the position that is advocated here, namely, that the true witnessing of His names and attributes cannot possibly come to pass inside the created realm, and nor is it a matter of perceiving God's reality outside of it in His own realm. There is no way that these two realities can merge.

Indirectly targeting the Akbarian school, al-Wāsițī cautions that a negligence of this differentiation will lead to the profession of divine incarnation $(h u l \bar{u} l)$ and unification $(i t t i h \bar{a} d)$. As he explained in the last quote above, it should not be said that what is perceived is God's actual reality and nothing else, nor should it be said that it is something other than Him. If, for instance, the light of divine majesty $(j a l \bar{a} l)$ is witnessed in the heart, then this is not identical with God's actual majesty - which, al-Wāsițī reminds his audience, neither heaven nor earth could bear. Rather, what is seen is a trace (athar) of His light that signifies this particular attribute due to its nearness to the heart in the unseen (al-ghayb). Nothing of God ever merges with anything, but $\mathrm{He}$ can be manifest to the heart in a true sense:

The heart's attachment [to God] does not resemble the attachment of physical bodies, because the heart is something unseen that is able to witness matters of the unseen (al-ghuyüb) without distance, and see them and be with them in truth. Even though this reality [of the unseen] exists and is tasted, seen by the taster in his human existence in accordance with his mirror, it [also] agrees with the reality outside [the created realm] (al-amr al-khārijī). Indeed, the reality as it is outside [the created realm] is the existence of the Lord (T), Who is highly exalted over His creatures with His essence above the Throne. ${ }^{37}$

Thus, what is witnessed by the heart in the unseen is not in disagreement with God's existence outside the created realm, but neither can it be taken to be of the same nature as the actual reality of His divine essence. Al-Wāsiți illustrates that it is like the difference between the name and the named:The name is not different from the named, but they are not identical either. ${ }^{38}$ As a parable, he

37 Al-Wāsițī, Risālatuhu ilā al-shaykh al-Maghribī, p. 111.

38 Al-Wāsițī, Qā'ida fì dhikr al-karāmāt al-múajjala li-al-munqațiīin ilā Allāh 'azza wa-jalla fì al-dunyā, pp. 287-288; Risālatuhu ilā al-shaykh al-Maghribī, p. 111; Miftāh al-ma'rifa, p. 264 . 
urges his readers to reflect on the difference between candlelight that falls upon a wall and the actual light that is held in the fire of its lit wick. The former light is in accordance with its locus, the wall, and the latter light is in accordance with its essence, the fire. Hence, the light that falls on the wall is not identical with light as it exists in its essence, but neither is it a different light. ${ }^{39}$

The human heart is, in short, something in between the transcendent and the immanent, wherein God and His servant, despite their essential contrariety, can achieve a connection by means of similitudes of God's magnificence. In that capacity al-Wāsiți calls the heart "the throne ('arsh) of the most exalted similitude,"40 which functions as "a veil (hijāb) between the servant and the reality of [God's] essence."41 Again, what is witnessed therein by no means renders God into an actual body or accident, for the heart is but a mirror that reflects traces of divine light(s) in accordance with its imperfection as a created, finite entity. The person who witnesses perceives this reflection in the form of a similitude that is limited to the way existence manifests in the heart, wujüd $q a l b \bar{\imath}$, and in no way similar to the reality of God's existence in His essence, wujūd 'aynī. ${ }^{42} \mathrm{Al}-W a \overline{s i t} i \overline{1}$ was convinced that he had thereby solved the problem of a this-worldly witnessing of God without breaking the established theological boundaries that safeguard His divine perfection.

It must be noted that, although the Taymiyyan spirit is certainly present in this discourse, al-Wāsițị's effort to write from the angle of Sufism does set it apart from the teachings of his Hanbali master and brings a breeze of originality to it. For example, Ibn Taymiyya similarly refers to the most exalted similitude as the 'medium' (tawassut) by which the servant knows God in his heart and serves Him, but I have not found him explicitly using this interpretation with the same vigor as al-Wāsițī in relation to the subject of witnessing God. ${ }^{43}$

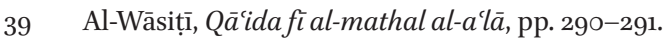

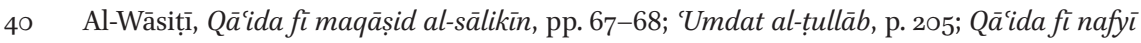
al-khawātirir, p. 246.

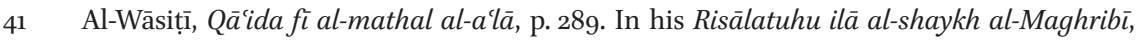
p. 111, where he similarly says that the heart "is a veil in respect to the hidden, essential reality [of God's Being]" (hijābun bi-nisbat al-amr al-khafìal-'aynī).

Al-Wāsițī, Risālatuhu ilā al-shaykh al-Maghribū, p. 112. We must note here that he did not intend to thereby negate a human vision of God in His essence. On several occasions he reminds his audience that direct contact between God and servant in the literal sense will occur in the afterlife, as only then God will be perceived as He truly is. Until that time, however, God's essential existence remains hidden from human beings - and from the entire created, temporal realm for that matter - and what we see of Him are "similitudes of His magnificence" that are witnessed in the heart. Cf. al-Wāsițī, Q̄àida fí al-mathal ala' lā, pp. 289-29o; 'Umdat al-țullāb, p. 213; Risālatuhu ilā al-shaykh al-Maghribī, pp. 111-112. See for instance: Ibn Taymiyya, $M F$, vol. 5, pp. 465-466; vol. 6, p. 27; vol. 35, p. 275. 
We may therefore take this as yet another indication that our Iraqi Sufi would operate within the same traditionalist framework as his shaykh, but with his own input from the viewpoint of the discipline of Sufism.

\section{3} The Sequence of the Degrees of Witnessing (Tartīb al-Mashāhid)

Now that we have discerned how al-Wāsiți conceived the process of witnessing, we may turn to the actual sequence of its degrees from beginning to end. It is no easy task to extract this sequence from his writings. Although he believed that every name or attribute of God should be witnessed, I have found him elaborating specifically on only ten of them. ${ }^{44}$ The occasional minor inconsistencies in their details scattered throughout his work may be an indication that his formalization of this aspect of his doctrine was a work in progress. In most cases where he mentions particular degrees of witnessing he does not specify their order, and there are a few significant differences between those instances where he does. For example, the 'witnessing of divinity' (mashhad al-ilähiyya) is always put before the 'witnessing of lordship' (mashhad alrubübiyya), except in the book Madkhal ahl al-figh wa-al-lisān, where it is the other way round. Moreover, there are several degrees of witnessing whose exact position in al-Wāsițis's sequence remain unclear because they only sporadically appear throughout his writings, such as the 'witnessing of withness' (mashhad al-maiiyya) and the 'witnessing of divine judgment' (mashhad al-

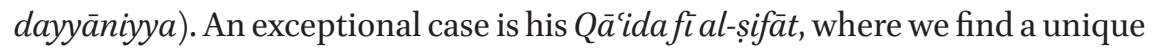
sequence that diverges considerably from others, containing several degrees that are not mentioned elsewhere.

The table on the next page gives an overview of which degrees are named across al-Wāsițî's works: The row headers contain the treatises' titles in alphabetical order, the column headers give the name of the degree(s) of witnessing mentioned therein. As can be seen, there are two degrees that are designated by two interchangeable terms: al-rubūbiyya/al-qayyūmiyya and al-jam'/alfardāniyya. Wherever degrees of witnessing are mentioned in a particular order this has been indicated by numbers; where no order is specified, their presence is simply marked by an ' $x$.' In both cases the corresponding page number(s) follows in superscript.

\footnotetext{
44 That all names and attributes can be witnessed is evident from al-Wāsițī's Qãcida ya'rifu al-'abd fíhā nașïbahu, pp. 210-212.
} 


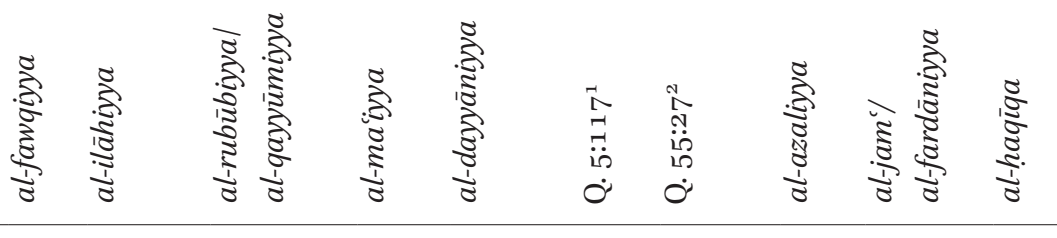

\begin{tabular}{|c|c|c|c|c|c|c|c|}
\hline Al-Sirr al-mașūn & & $1^{47-50}$ & $2^{47-50 / 62}$ & & & $3^{64-67}$ & \\
\hline Madkhal ahl al-fiqh & $2^{79}$ & $3^{79}$ & $1^{78-79}$ & $4^{79}$ & & $5^{79^{-80}}$ & \\
\hline Miftāh al-ma'rifa & & $\mathbf{1}^{265}$ & $2^{265^{-266}}$ & $3^{267}$ & & $4^{267-268}$ & \\
\hline Mizān al-shuyūkh & & $\mathrm{X}^{241}$ & $\mathrm{X}^{241}$ & & & $\mathrm{X}^{241}$ & \\
\hline $\begin{array}{l}\text { Qāंida fíal-farq } \\
\text { bayna al-‘̄abid } \\
\text { wa-al-mushāhid }\end{array}$ & & & & & & $\mathrm{X}^{260-262}$ & \\
\hline $\begin{array}{l}\text { Qāंida fi al-farq } \\
\text { bayna mushāhadat } \\
\text { al-qayyūmiyya }\end{array}$ & & & $1^{263-264}$ & & & $2^{263-265}$ & \\
\hline Qāंida fi al-șifāt & $1^{321}$ & $2^{321-322}$ & $3^{322}$ & $4^{322}$ & $5^{322} \quad 6^{322-323} 7^{323}$ & $8^{323}$ & $9^{323}$ \\
\hline $\begin{array}{l}\text { Qāंida fí al-umūr } \\
\text { al-muwașsila }\end{array}$ & & & & & & $\mathrm{X}^{222-226}$ & \\
\hline $\begin{array}{l}\text { Qāंidafi aṣnāf } \\
\text { al-ta'alluh }\end{array}$ & & $\mathrm{X}^{154}$ & $\mathrm{X}^{154}$ & & & $\mathrm{X}^{154-155}$ & \\
\hline Qāंida fi habs al-nafs & & & & & & $X^{89-90}$ & \\
\hline $\begin{array}{l}\text { Qāंida fi istijlāb } \\
\text { al-widād }\end{array}$ & & & & & & $\mathrm{X}^{275^{-2}} 7^{6}$ & \\
\hline $\begin{array}{l}\text { Qāida fìmazāhir } \\
\text { al-shuhūd }\end{array}$ & & $1^{140-141}$ & $2^{141-143}$ & $3^{143^{-144}}$ & & $4^{145^{-148}}$ & \\
\hline $\begin{array}{l}\text { Qāंida fi sulūk } \\
\text { al-awliy } \bar{a}^{\prime}\end{array}$ & & $\mathrm{X}^{164}$ & $\mathrm{X}^{164-168}$ & & & & \\
\hline
\end{tabular}

Qāंidafisulūk $\quad \mathrm{X}^{200-201} \mathrm{X}^{200-201}$

al-tahqiq

Qāidafial-tajrìd $\quad \mathrm{X}^{25^{2}} \quad \mathrm{X}^{25^{2}} \quad \mathrm{X}^{25^{2}} \quad \mathrm{X}^{25^{2}} \quad \mathrm{X}^{25^{2}} \quad \mathrm{X}^{25^{2}}$

Qāंidamin 'alāmāt $\quad \mathrm{X}^{169-172}$

al-tahqūq

Qā'ida ya'rifu al-'abd

$\mathrm{X}^{212}$

fìhā nașībahu

Sharh Manāzil

al-sä'irīn ${ }^{3}$

Talqīh al-afhām

$\mathrm{X}^{15^{6}} \quad \mathrm{X}^{15^{6}}$

$\mathrm{X}^{162}$

Umdat al-țullāb

$\mathrm{X}^{205} \quad 1^{210-211} 2^{211}$ 
1 This is the degree of witnessing God as the Watcher over mankind, as stated in the Qur'anic verse "You were the Watcher over them (al-raqib 'alayhim) ..."

2 This is the witnessing of the verse "but the Face of your Lord will remain, Master of majesty and glory."

3 We owe a passage from this commentary about $\operatorname{fan} \vec{a}, b a q \bar{a}^{3}$, and jam ' to Ibn al-Qayyim's Shif $\vec{a}^{\prime}$ al-'alïl, p. 16.

In spite of the obvious inconsistencies visible above, there is also a common thread. There are three degrees of witnessing that consistently recur: (1) the mashhad al-ilāhiyya, (2) the mashhad al-rubübiyya/al-qayyūmiyya, and (3) the mashhad al-jam/al-fardāniyya. This is no coincidence. In both Madkhal ahl al-figh wa-al-lisān and Qã'ida fí așnā al-ta'alluh al-Wāsițī explains that the sequence of witnessing God consists of three categories: First, those that pertain to God's law, which come together under His divinity (ilāhizya) that alone deserves to be worshipped; and, second, those that pertain to God's actions ( $\left.a f^{\prime} \bar{a} l\right)$, which come together under His lordship (rubübiyya) over the creation. Both degrees of witnessing are held in the heart. As for the third degree, this revolves around the notion that every name and attribute is but a constituent part of God's Being - al-amr al-juz'̄ - that belongs to His essence (dhāt), wherein the complete reality of His Being - al-amr al-kulli - comes together. ${ }^{45}$ The latter category is beheld when union (jam $)$ and singularity (fardāniyya) are witnessed, which occurs in the spirit. It is in this final degree that the sâlik arrives unto God and al-Wāsiți’s spiritual journey effectively comes to an end. We can thus conclude that the variations found in his writings are not such that it becomes impossible to detect something of a coherently structured system in his doctrine of witnessing. How he gave meaning to this doctrine we will analyze in the remainder of this chapter.

\subsection{The Heart's Witnessing of Divinity (Mashhad al-Ilāhiyya)}

In the following passage, al-Wāsițī imagines the manifestation (tajallī) of God's divinity, which is how the sālik may hear God address him through the Qur'an and the hadīth, manifesting His ilähiyya to him:

"I am God, there is no deity but Me!" [Q. 20:14]. These are My signs and My proofs, My arguments and My guidance. I speak through this [i.e. the Qur'an and hadith]: I command through what I command through it, I forbid through what I forbid through it, I cause fear through the fear that I cause through it, and I give hope through the hope that I give through it. So listen to My tales, obey My command, and follow My Messenger. I am 
unique in My essence and My magnificence ('azama) is above the seven heavens. Cognizant of My servants, I know their secret thought and their secret discourse. So worship Me and do not attribute anything to Me! Here I am with you, so do not think of Me as being far from you. Between you and the Afterlife there is but a veil which death will uncover. Then you will see Me manifestly, and you will see the veracity of My threat (waid) by which I filled you with fear and which I warned you about, and the veracity of My promise ( $w a^{\prime} d$ ) for which I gave you hope and which I made you desirous of and long for! ${ }^{46}$

This tajalli subtly illustrates how our Iraqi Sufi perceived, what is in the vast majority of his writings, the first category of witnessing. That he carefully chose his words to describe this experience will become apparent if we read it in the context of his other work on the subject.

As he saw it, the term 'ilähiyya' refers to God being 'al-iläh' the Divine, and as such the object of worship ( $\left.a l-m a^{\prime} b \bar{u} d\right)$ by means of the religion He revealed. God has made Himself known to mankind in that capacity through His Prophets and Messengers, His laws, and what He has made legally obligatory, recommended, or encouraged, so that they may thereby serve Him, worship Him, seek Him, love Him, and reach nearness to Him. ${ }^{47}$ Hence, divinity is witnessed as God speaking through the Qur'an with those words by which He imposes these things upon His servants (al-kalimät al-taklïfiyyāt). ${ }^{48}$ In other words, in the Qur'an God clarifies His commands and prohibitions and what He has made lawful and unlawful, rulings to which the sālik must submit with patience and contentment and without dispute. According to al-Wāsițī, this is the meaning of the Qur'anic verse "But no, by your Lord! they will not believe till they make you [the Prophet] the judge regarding the disagreement between them, then they shall find in themselves no impediment touching your verdict, but shall surrender in full submission" [Q. 4: 65] ${ }^{49}$ Evidently, in order to perform the requirements of God's divinity one must first have knowledge, ma'rifa, of its particularities.

In order to reach this márifa, al-Wāsiți relies on the aforementioned effort to recite the Qur'an while reflecting on it in order to become acquainted with the meanings of the divine names and attributes it contains. One will thereby not only know the attributes explicitly mentioned, he says, but also those that

\footnotetext{
46 Al-Wāsițī, Q̄àida fì mazāhir al-shuhūd wa-al-ma'rifa, pp. 140-141.

47 Al-Wāsițī, al-Sirr al-mașūn, p. 5o; Miftāh al-márifa, p. 265.

48 Al-Wāsițī, Miftāh al-márifa, p. 266.

49 Al-Wāsițī, al-Sirr al-mașūn, p. 47.
} 
are implicitly present. For sometimes God speaks with words that reveal His commands and prohibitions, sometimes they reveal His promise and threat, sometimes His magnificence and power, sometimes His mercy and generosity towards His servants, sometimes His subjugation of His enemies, and so on. ${ }^{50}$ As opposed to God's active attributes that pertain to His lordship (rubübiyya) by which He constantly brings into being, governs, and controls His creation, these all pertain to the reality of His revealed religion by which His divinity is given its due. After extracting them from the revelation, al-Wāsiți teaches at least two ways to invoke the practices that are meant to result in the realization of ilāhiyya.

The first is to reach the degree of witnessing God's aboveness (mashhad alfawqiyya). Although this is only indirectly hinted at in the tajalli with which we opened this section, al-Wāsiți held that the witnessing of divinity is preceded by the witnessing of aboveness. In Madkhal ahl al-figh wa-al-lisān he states that this follows after having gained the required knowledge of the aforementioned attributes of divinity through the recitation of and reflection on the Qur'an:

Marifa of the divine attributes ... becomes manifest in the purity of [one's] heart while observing the revealed law and reciting the divine revelation (al-wahì al-ilāhi) within which the command and prohibition, the promise and threat, and other such things are contained. When the heart immerses itself therein and becomes absent in these meanings (ma'ānì) [from the Qur'an], the witnessing of aboveness appears to the heart. ${ }^{51}$

It appears that its merit to the witnessing of ilähiyya lies in the knowledge that God manifests His attributes and their meanings through the Qur'an from above the seven heavens over the Throne; it is from there that He constantly sees each and every one of His servants, ever knowing whether $\mathrm{He}$ is given His full due by them or not. Al-Wāsiți believed that when the sālik becomes truly conscious of God's sight upon him from above, he will naturally hold Him in awe and reverence, and feel shy and ashamed before Him..$^{52}$ A recurring method he proposes to train oneself in this sense of shame is to go into seclusion (khalwa) in a dark room or cave for an hour each day, to leave the world behind

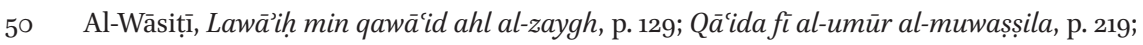
'Umdat al-țullāb, p. 206; Madkhal ahl al-figh, p. 79 .

$51 \quad$ Al-Wāsițī, Madkhal ahl al-figh, pp. 78-79.

52 Al-Wāsițī, Qā'ida fì al-șifät, p. 321; Miftāh al-márifa, pp. 265-267; Qā'ida mukhtașara, pp. 28-29; Miftāh țarīq al-awliyā̇, pp. 34-35; Qā'ida fì bayān al-țarīq ilā Allāh, p. 181. 
and focus only on God and supplicate Him. ${ }^{53}$ This should then motivate the sălik to uphold vigilant awareness (murāqaba) of all his movements and passing thoughts (khawātirir), constantly take himself to account (muhāsaba) for them, and guard his body parts (ricāya) so as to keep them conforming to God's commands and prohibitions with sincerity. ${ }^{54}$ We may note that such techniques had been incorporated into Sufism since its early formation, so al-Wāsițī undoubtedly relied on the teachings of his Sufi predecessors here.

The second way he mentions to invoke practice on the path towards witnessing divinity was also alluded to in the tajalli, and revolves around careful reflection on God's promise (wa'd) and threat (waid) as articulated in the revelation. In al-Sirr al-mașūn he explains that, on the one hand, the Qur'anic references to the promise of eternal happiness for the triumphant (al-fäizün) should arouse a desire in the heart to obey God's commands and perform the obligatory and recommended acts of worship for the sake of this great reward; on the other hand, the Qur'anic references to the threat of the hellfire and its punishments should arouse the desire to drive away the carnal soul from inclining to that which God has forbidden, and to take oneself to account and guard one's body parts. Thus, he concludes, the combined reflection on God's promise and threat gives both hope (rajä) and fear (khawf), which should aid the sālik in bearing the burden of obedience to God's law with patience and contentment. ${ }^{55}$

By having realized consciousness of God's sight from above, and hope for His promise and fear of His threat, al-Wāsițī believed that divinity can truly be given its due through close adherence to the revealed law:

When the servant restricts himself to the Muhammadan revealed command (al-amr al-mashrü' al-Muhammadì), his aspiration becomes united, his energy devoted to upholding what is commanded [by God] and

53 Al-Wāsițī frequently mentions seclusion (sing. khalwa, pl. khalawāt) in his works as an effective method to reflect on God and His revelation, invoke Him, and build a relationship with Him; see: Q̄̄ंida fì tasfiyyat al-akhlāq, p. 89; Qāंida fì bayān al-țarìq ilā Allāh, p. 181; Qā'ida fì dhikr al-karāmāt al-mu'ajjala li-al-munqațiīn ilā Allāh 'azza wa-jalla fì al-dunyā, pp. 283-284; al-Tadhkira, p. 27; Madkhal ahl al-fiqh, pp. 59-6o; Miftāh țarīq al-awliyä, p. 34; Talqüh al-asrār, pp. 49-5o; Q̄̃̄ida fì an al-'abd yata'ayyan 'alayhi ma'rifat al-țarìq ilä Allāh 'azza wa-jalla wa-al-ta'arruf lahu, p. 114.

54 The terms murāqaba, muhāsaba, and ricāya occur regularly throughout al-Wāsițî̀s writings and are not exclusively mentioned in the context of fawqiyya. In the following titles he also elaborates on how to apply them: Qāंida fi al-umūr al-muwașșila, p. 217; Talqüh al-afhām, p. 158; Mīzān al-shuyūkh, p. 240; Madkhal ahl al-figh, pp. 61-63, 75-77.

55 Al-Wāsițī, al-Sirr al-mașūn, pp. 47-50; see also his: Lawāiḥ min qawāid ahl al-zaygh, p. 129; Q̄ãida fì bayān al-țarīq ilā Allāh, p. 181. 
hastening towards the object of his search, and he employs whatever is sweet to his heart of the revealed acts of worship and commendable ways to remember [God] (al-adhkār al-mandūba). Indeed, he should constantly practice the remembrance of God that is sweet to his heart, for when something from that has become sweet, it is hoped that he is provided with an opening therein! ${ }^{56}$

Clearly aiming to criticize what he considers extreme ascetic interpretations of Sufism, al-Wāsiți emphasizes close adherence to the Prophet's example, the Sunna, rather than adopting practices that are not explicitly revealed by God (ghayr mash $r \bar{u}$ ). For instance, he strongly disapproves of constant fasting, and instead advises to simply lessen the amount one drinks and eats slightly, and to practice supererogatory fasting only on Mondays and Thursdays in accordance with the Sunna. ${ }^{57}$ His method of sulük thereby takes a distinctly sharíagrounded approach to Sufism by relying solely on acts of worship that have been transmitted via the nușuṣs.

It will be useful to take a look at the central role he allots to the Muslim ritual prayer $(a l-s ̦ a l a t t)$, in particular as a fitting example of this approach. He frequently mentions the significance of perfecting one's performance of the prayer as a means to draw near to God. The șalät is, as he calls it, the touchstone (mihakk) for one's spiritual state or station, as it is a moment of contact with God. He explains that if one has mastered the state of fear or love for God, this should be visible in the way one prays. If this is not the case, then one can be sure that they are not yet acquired these states. ${ }^{58}$ Because he considers the prayer a moment purely for God, he argues that it is to be performed with full attentiveness $(h u d \bar{u} r)$ from the very moment it is entered by pronouncing the 'takbir,'59 making sure that the heart remains guarded against distracting whispers (waswās); then the meanings of every word of the Qur'an recited should be understood so that it becomes as if one stands directly before God, conversing with Him. ${ }^{60}$ Besides perfecting the act of prayer itself, al-Wāsițī also emphasizes the importance of performing each particular prayer on its

$56 \quad$ Al-Wāsițī, 'Umdat al-țullāb, p. 210.

57 Al-Wāsițī, Miftāh al-márifa, p. 272.

58 Al-Wāsițī, Madkhal ahl al-figh, p. 68; Qāंida mukhtașara, p. 32.

59 The Muslim ritual prayer begins from the moment the first takbir - i.e. 'Allāhu akbar' (God is great) - is pronounced.

6o Al-Wāsițî, Qã'ida mukhtașara, pp. 30-32; Qã̄ida fí bayān 'amal yawm wa-layla li-al-abrār wa-'amal yawm wa-layla li-al-sā̉irìn ilā țarìq al-muqarrabīn ja'alnā Allāh minhum, p. 71; Qã̄ida fì istijlāb al-widād, pp. 276-277; Miftāh țarīq al-awliyā', pp. 35-36; Madkhal ahl alfigh, pp. 68-69. 
specific time, such as the voluntary prayer in the last third of the night (altahajjud), the Friday prayer (șalät al-jumu'a), and the times of the five communal prayers - because, "during these [moments] allotments [from God] descend upon the seekers, and divine gleams (bawāriq) shine upon the hearts of those who yearn [for Him] and love [Him]."61

For al-Wāsițī, it is only by vigilantly abiding by the shar ${ }^{i}$-ordained practices of worship that God will reveal the witnessing of knowledge of His attribute of divinity (mashhad ma'rifat sifat al-ilähiyya). He cautions, however, that God's gifts are according to one's ability to receive them, so it may be that the heart only sporadically perceives the realities of divinity and that they may just as fast disappear. Only when witnessing is done uninterruptedly, one knows that the heart has come to inhabit it as a spiritual station (maqām). Al-Wāsițī defines this station as a profound understanding of the Qur'an, wherein the light of the Prophet and the intimate knowledge of him and his Companions manifests. That is so, he explains, because they were the transmitters of the message (al-risāla) by which God's divinity and its requirements has been made known. Pure faith in divinity is therefore only acquired through them. ${ }^{62}$ Having thus realized the witnessing of divinity by means of its duties, the next step in the sequence of al-Wāsițîs sulūk is to witness the attribute of God's lordship.

\subsection{The Heart's Witnessing of Lordship (Mashhad al-Rubübiyya)}

After the tajallı̄ of God's divinity, al-Wāsiți likewise imagines the tajallı̄ of His lordship, which is how the sălik may hear God address him, manifesting His rubübiyya to him through His activity in the created realm:

"I am God, there is no deity but Me" [Q. 20:14], the Creator (al-khäliq), the Maker (al-bāri'), the Shaper (al-mușawwir), the Ever-Living (al-hayy), the Sustainer (al-qayyūm), the Director (al-mudabbir), Who creates the creation and spreads out provision. It is I who brought into existence this world, which you see was unprecedented! I decree the appointed time for all those who live in it, assign their provisions, and direct their affairs by the direction of My creative power (qudra) in accordance with My wis$\operatorname{dom}($ hikma). You see that [creatures] do not in themselves possess benefit or impairment, death, life, or resurrection - for who other than I calls them into being, and sustains and furnishes them? Who provides for

61 Al-Wāsițî, Umdat al-țullāb, p. 210; see also his: Miftāḥ al-ma'rifa, pp. 272-273; Miftāh țarīq al-muhibbīn, pp. 279-280; Qā'ida fì bayān 'amal yawm wa-layla, p. 72.

62 Al-Wāsițī, 'Umdat al-țullāb, pp. 210-211; Lawā̉iḥ min qawā'id ahl al-zaygh, p. 129; Qā'ida fì maz̄āhir al-shuhüd, p. 141. 
their needs? Who shapes their wondrous forms, gives them their marvelous colors, and spreads among them a variety of souls with extraordinary characteristics, each different from the other ... All this comes from My governance and My ordainment in accordance with My volition and will, which flow from the ordinances of My wisdom - "Is there a deity with God? Highly exalted be God above that which they associate!" [Q. 27:63] - So trust in Me, fear Me, and commit all your affairs to Me, for I control all things! ${ }^{63}$

As with the former category of divinity, we will again see that this tajalli aptly illustrates how al-Wāsiți perceived the witnessing of lordship.

The term 'rubübiyya' refers to God being 'al-rabb,' the Lord and Sovereign, and as such the sole force that brings into being and moves all creatures. Simply put, al-Wāsiți defines it as follows: "the attribute of rubūbiyya is the Lord's (T) solitariness in directing and sustaining [all creatures] (infiräd al-rabb bi-altadbìr wa-al-qayyūmiyya)." ${ }^{4}$ In that capacity, al-Wāsiți explains that God has complete and absolute authority over all creatures, sustains them, and nourishes them inwardly and outwardly with His blessings and bounties, thereby making Himself known to them. ${ }^{65}$ Apart from within the creation itself, he teaches that this part of God's Being also manifests in the Qur'an through the words by which He brings into existence (al-kalimāt al-takwiniyyāt), such as the verse "The only words We say to a thing when We desire it, is that We say to it 'Be,' and it is" [Q. 16:40]. ${ }^{66}$

It must be noted here that al-Wāsiți sometimes uses 'qayyūmiyya,' 'sustainment,' as a synonym for rubübiyya. The former term signifies God's fulfilment of the divine name 'al-qayyüm, 'the Sustainer,' which was, of course, not coincidentally mentioned in the above-quoted tajalli as well. ${ }^{67}$ Hence, when in some of his works he speaks of the mashhad of qayyümiyya and in others of the mashhad of rubübiyya, he is in fact referring to one and the same act of witnessing.

\footnotetext{
63 Al-Wāsițī, Qācida fìmažăhir al-shuhūd, pp. 141-142.

64 Al-Wāsițī, Umdat al-țullāb, p. 211.

65 Al-Wāsițī, al-Sirr al-mașūn, p. 5o.

66 Al-Wāsițī, Miftāḥ al-márifa, p. 266.

67 For the proof that al-Wāsiți viewed rubūbiyya and qayyūmiyya as synonyms, see the above quote from 'Umdat al-țulāab, p. 211, and also: Qāंida fì sulük al-awliyā', pp. 164-165, where he speaks of witnessing qayyumizya, "during which the servant concedes to be guided by servitude, humble before the principles of rubūbiyya." He also clearly connects both terms in: Qāंida fı̈mazāhir al-shuhüd, p. 141.
} 
If ilāhiyya required that the sālik reflect on God's Self-manifestation in the nușūs, rubübiyya requires that he reflect on God's actions ( $\left.a f^{\prime} \bar{a} l\right)$ that constantly manifest in the created realm. ${ }^{68}$ In Madkhal ahl al-figh wa-al-lisān al-Wāsițī states that

[h] e should reflect "... on the dominion of the heaven and of the earth, and what things God has created" [Q. 7:185] such as the sun and the moon, the stars and celestial bodies that circulate, the winds that blow, and the seas [waves] that crash. This will open him up to intellectual knowledge ( ${ }^{\mathrm{i}} \mathrm{im}$ ) of the origination and procreation of existents, descendants one after the other. When his thought is immersed in this, the light of intimate knowledge (márifa) will appear to his innermost secret (sirr) by means of reflection on these actions. Now this is what is called ma'rifa of God ('AJ) through His actions, which is above [mere] faith in Him. ${ }^{69}$

In other words, ma'rifa of God's lordship pertains to intimate knowledge of the activity in the creation of the earlier-mentioned category of divine attributes called 'active attributes' (șifät fíliyya). According to al-Wāsițī, this knowledge brings one to understand that nothing moves or stands still, nothing contracts or expands, nothing is lowered or raised except that God is its Doer through these attributes; all emanates from His creative power (qudra).${ }^{70}$ So, he says, when the sālik becomes a knower ('ärif) of these meanings (ma'ānī) and its realities thus become unveiled, then all existents take him back to God, so that the creation no longer veils him from its Creator. ${ }^{71} \mathrm{He}$ then witnesses that God sustains all existents, which may cause him to become absent from them altogether as he only sees God's will unfold by them. When this persists he ascends to what al-Wāsiți calls the station (maqām) of witnessing lordship. ${ }^{72}$

Like the witnessing of divinity, he teaches that this degree is brought to realization by means of specific practices. These fall under the category he calls 'servitude ('ubüdiyya) of lordship,' which he discusses quite extensively throughout his writings. A maxim he very frequently repeats is that the sālik must completely reject the notion of having any choice or self-direction (tark

\footnotetext{
68 Al-Wāsițī, Qā'ida fì bidāyāt al-awliyā', p. 175.

69 Al-Wāsițī, Madkhal ahl al-figh, p. 78.

70 Al-Wāsițī, Miftāḥ al-ma'rifa, p. 266; 'Umdat al-țullāb, p. 211; Qā'ida fì sulūk al-awliyā', pp. 164-165; Q̄̄ंida fi bidāyāt al-awliyā', p. 174.

71 Al-Wāsițī, Qā'ida fìmazāhir al-shuhūd, p. 142.

72 Al-Wāsițī, Qāंida fí al-farq bayna mushāhadat al-qayyūmiyya wa-al-tahaqquq bihā, p. 263; Qā'ida fì mazāhir al-shuhūd, pp. 142-143.
} 
al-ikhtiyār wa-al-tadbīr) to compete with God's decree. ${ }^{73}$ After all, he says, "with respect to [God's] direction the servant's self-direction is a frivolity that comes from his human nature (bashariyya) due to being blind to [God's] sustainment (qayyümiyya)." ${ }^{74}$ Seeing that autonomy and independency do not truly exist, al-Wāsițī sees no other choice but to trust in God's decree (tawak$k u l$ ) and commit all affairs to Him (tafwie $)$ ), as alluded to by the Qur'anic words "the affair belongs entirely to God (al-amr kulluhu li-lläh)" [Q. 3:154]. ${ }^{75} \mathrm{He}$ argues that when the meaning of this verse becomes firmly established in the heart, the sālik will come to understand its reality and become one in need (faqir) of his Master with his entire being. ${ }^{76}$

All this is aimed at what he refers to varyingly as the 'unification' (ittihād), 'union' (jam ), or 'conformity' (muwäfaqa) of the sālik's will with the divine will (al-iräda), a state he considers the utmost degree of realizing God's lordship. ${ }^{77} \mathrm{He}$ describes those who reach this as follows:

The majority of their affair is conformity (muwäfaqa) [with God's will] regarding all things - or rather, it is annihilation $\left(\right.$ fan $\left.\bar{a}^{\prime}\right)$ in conformity without conformity, by the divine decrees (ahkām) that flow upon them from their sources. They perceive these, ever depending on the good of [God's] direction (tadbir) [of their affairs], carrying out His commands and fleeing from His prohibitions by implementing what He revealed amongst them, which withholds them from [doing] what He dislikes.

The sālik's rejection of ikhtiyār and tadbìr are mentioned in al-Wāsițìs al-Sirr al-mașūn, pp. 61-62; Qā'ida fì bayān 'amal yawm wa-layla, pp. 74-76; Qā'ida fì tasfiyyat al-akhlāq,

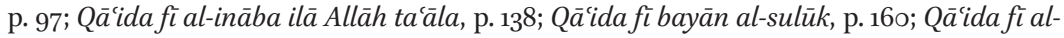
umūr allatīyanbaghī an takūn hamm al-sālik, p. 196; Qā'ida fì al-umūr al-muwașșila wa-al-

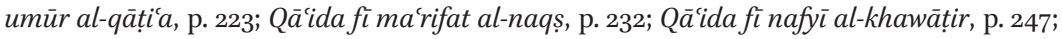
Qāंida fì al-jidd wa-al-ijtihād, pp. 249-25o; Q̄̄ंida fì dhikr al-karāmāt al-mu'ajjala, p. 286; Q̄̄ंidat al-rūhānniyyāt, p. 296; Qawā'id al-nubuwwāt, p. 301; Qā'ida fì al-șifät, p. 322; Talqüh al-afhām, p. 162; Miftạh al-ma'rifa, p. 269.

74 Al-Wāsițī, Qã ida fì al-umūr allatìyanbaghī an takūn hamm al-sālik, p. 197.

75 For references to tawakkul and tafwị̀, see al-Wāsițīs Miftạh al-márifa, p. 266; Madkhal

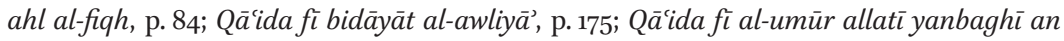
takūn hamm al-sālik, p. 197; Qāida fì al-umūr al-muwașșila, p. 223; Qā'ida fì márifat al-naqș, p. 237; Qā'ida fì nafȳ̄ al-khawāțir, p. 246; Qāंida fì al-jidd wa-al-ijtihād, p. 249; Qāंidat al-rūhāniyyāt, p. 296; Qawā'id al-nubuwwāt, p. 301.

76 The notion of becoming in need of God by realizing rubūbiyya is stated in al-Wāsițīs Qāida min 'alāmāt al-tahaqquq bi-al-qayyūmiyya, p. 169, and in Madkhal ahl al-figh, p. 84.

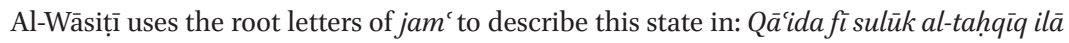

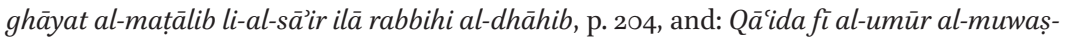

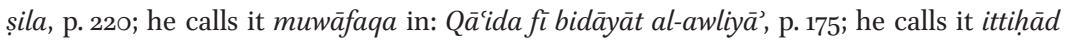

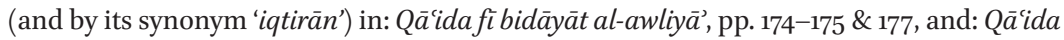
fì al-farq bayna mushāhadat al-qayyūmiyya, p. 264. 
Hence, [all] they do is for Him and through Him, and they perceive His disposal (tașrîf) of them in their deeds. So glory be to the Doer of what He desires! All those who are servants in His hand serve Him in this domain (mawtin) through the acts of servitude towards [His] lordship. ${ }^{78}$

The acts of servitude towards God's lordship are the above-mentioned practices of leaving one's choice and self-direction and trusting in Him and committing one's affairs to Him. Al-Wāsiți believed that when this servitude is mastered by the sālik, God's creative power (al-qudra) will take a hold of him; he thereby separates from his own 'self' (infișāl 'an al-nafs) by connecting with God spiritually (al-ittișāl al-mánawù̄). As this occurs, al-Wāsițī says the sālik will continue to heed the divine decree and command without being attentive thereof, for God, the Actor (al-fāil), becomes one and the servant merely acted upon (munfa $\left.{ }^{c} i l\right) .{ }^{79}$ This appears to be what is intended when he spoke of those who reach annihilation $\left(\right.$ fana $\left.\bar{a}^{3}\right)$ in conformity without conformity, which we may understand as a state wherein one's finite human will conforms with God's eternal will, so that it is blotted out in the will of God. Consequently, one can no longer speak of conformity, since only the will of God remains.

When witnessing lordship is thus realized in combination with divinity, alWāsițī considers this the fulfilment of "You alone we serve, You alone we ask for help" [Q. 1:5], the supplication from the first chapter of the Qur'an recited in each ritual prayer. He explains that the first half of this Qur'anic verse is put in effect by giving God's ilähiyya its due through the affirmation of the message (al-risāla) revealed to His Prophet and practicing its rules and regulations; the second half is put in effect by giving God's rubübiyya its due through the affirmation of Him as the sole Director of the creation and thus the sole source of succor. ${ }^{80}$ For al-Wāsițî, divinity and lordship are thus interconnected and in need of one another, so that the sālik's journey remains incomplete as long as one of the two is realized and witnessed without the other. It is only in combination that they are brought to perfection. ${ }^{81}$ As we have thereby reached the end of our analysis of the first two categories of witnessing, we can now point out where al-Wāsiți’s conception of them appears to draw from the teachings of his shaykhs.

\footnotetext{
78 Al-Wāsițī, Qā'ida fì bidāyāt al-awliyā', p. 175.

79 Al-Wāsițī, Qā'ida fì al-farq bayna mushāhadat al-qayyūmiyya wa-al-tahaqquq bihā, pp. 263-264; also clearly alluded to in: Lawä̀ih min qawā'id ahl al-zaygh, p. 13 o.

8o Al-Wāsițī, Umdat al-țullāb, p. 211; Miftāh al-ma'rifa, pp. 265-266.

81 Al-Wāsițī, Qā'ida fì mazāhir al-shuhūd, p. 143; Miftāḥ al-ma'rifa, pp. 266-267; Qā'ida fì sulūk al-tahquìq ilā ghāyat al-mațālib, pp. 200-201.
} 


\section{Al-Wāsițìs Shaykhs and Their Teachings Regarding Divinity and Lordship}

First, when it comes to servitude of God's lordship specifically, it is evident that he integrated the Shādhilī method of rejecting one's human choice and selfdirection, taught to him by Najm al-Dīn. ${ }^{82}$ We have seen in chapter 2 that this was indeed a characteristic element of the doctrine taught amidst the early Shādhiliyya.

Furthermore, when it comes to the notion that the unification and conformity of one's human will with the divine will is the utmost degree of realizing lordship, we find that al-Wāsiți probably relied on Ibn Taymiyya. He is likely speaking of his Hanbalī master when he writes that

[our] teacher (may God have mercy on him) has mentioned an issue (mas'ala) that I had forgotten about until a reminder from God ('AJ) occurred to my mind. It is as follows: There are people whose utmost degree is servitude ('ubüdiyya), but some of them ascend with servitude to something else altogether - and that is the right course! Indeed, there are some who travel the way [unto God] until they become intimately acquainted [with Him] (man yasluku hattāya'rifa). When this happens and they know the realities of the divine attributes, then these blot out their own will and their desire unifies with their Master's desire, thus becoming one - and that is His desire [alone]. ${ }^{83}$

Although it may be argued that the words "may God have mercy on him" suggest that a different teacher is intended - since Ibn Taymiyya outlived al-Wāsiți - I believe that this invocation may have been added later by a copyist. This is supported by the fact that Ibn Taymiyya actually held this very same position regarding conformity with the divine will, which he expressed as follows, in words very similar to those stated by al-Wāsiți above: "As for the servant knower of God, his desire is unified with the desire of God, so that he only desires what God desires ..." 84 In fact, the shaykh al-Islām considered this a distinct

82 This observation has also been made by Geoffroy, "Le traité de soufisme," pp. 87-88.

83 Al-Wāsițī, Qã ida fíal-farq bayna mushāhadat al-qayyūmiyya wa-al-tahaqquq bihā, p. 266.

84 Ibn Taymiyya, $M F$, vol. 11, p. 77: "wa-al-'abd al-'ârif bi-'llāh tattahidu irādatuhu bi-irādat Allāh bi-ḥaythu lā yurīdu illā mà yurīduhu Allāh." Compare this with the last sentence of the above quote from al-Wāsițī, which reads: "wa-'ttahadat irādatuhu bi-irādat mawlāhi fa-șārat wāhida wa-hiyya irādatuhu." I am indebted to Yahya Michot for pointing out the importance of muwāfaqa in the doctrine of Ibn Taymiyya. It has also been noted by Bell, Love Theory, pp. 76 \& 84 . 
feature of the so-called 'friends of God' (awliy $\bar{a}$ 'Alläh), as implied in al-Tuhfa al-Irāqiyya:

God (T) does not honor His servant with a miracle (karāma) more magnificent than his conformity (muwäfaqa) with what He loves and pleases Him, and that is obedience to Him and His Messenger, friendship with His friends, and enmity towards His enemies - such are the friends of God concerning whom God states: "Indeed, the friends of God will feel no fear and know no sorrow - they are those who have faith and piety" [Q. $10: 63-64] .^{85}$

Besides the notion of conformity, al-Wāsițī's theological basis for the witnessing of ilāhiyya and rubübiyya was in all likelihood adopted from Ibn Taymiyya as well. The latter is well known for distinguishing between both terms in his understanding of divine unity (tawhìd).${ }^{86}$ It was in all likelihood also Ibn Taymiyya's very own interpretation that the words of the fifth verse from the first chapter of the Qur'an embody the essence of divinity and lordship. The following commentary he gives on the verse correlates perfectly with the explanation of ilähiyya and rubübiyya as found in the works of al-Wāsiți:

[God's] statement "You alone we serve" refers to serving Him by what His divinity (ilähiyya) requires - such as [realizing] love, fear, and hope [in Him], and [observing] the command and prohibition - and "You alone we ask for help" refers to what His lordship (rubübiyya) requires - such as trusting [in Him], committing [all affairs to Him] (tafwìd), and submitting [to Him] (taslim ) - for the Lord (ST) is the Master! ${ }^{87}$

When the two halves of this verse are thus combined, Ibn Taymiyya concludes after this passage, they bring together all the secrets of the Qur'an. Like alWāsițī, he then goes on to emphasize that it is therefore necessary to witness divinity and lordship together, with the former referring to witnessing the revelation of God's religion ( $a l$-amr al-shar $(\bar{l})$, and the latter to witnessing God's acts of bringing into existence as He wills (al-amr al-kawnī al-irādī $){ }^{88}$ Also similar to al-Wāsiți in this regard is Ibn Taymiyya's position that God some-

85 Ibn Taymiyya, al-Tuhfa al-irāqiyya, p. 335.

86 The distinction between the unity of ilāhiyya and rubūbiyya as a typically Taymiyyan construction has been studied before. See for instance: Meier, "The Cleanest about Predestination," pp. 322-324; Hoover, Ibn Taymiyya's Theodicy, pp. 120-122.

87 Ibn Taymiyya, $M F$, vol. 1, p. 89 .

88 Ibid. pp. 89-9o; see also: $M F$, vol. 2, p. 320. 
times speaks with the attribute of divinity through the Qur'anic words that specify the religion He has revealed (al-kalimät al-diniyya), and sometimes with lordship through the Qur'anic words by which He brings into existence (al-kalimät al-kawniyya). ${ }^{89}$ Given that we know this to be a distinctly Taymiyyan approach to traditionalist theology, there remains little doubt that alWāsițīs teachings on divinity and lordship appropriated elements from the teachings of his Ḥanbalī master.

\subsection{Other Degrees of Witnessing by the Heart}

After divinity and lordship al-Wāsițī also designates 'withness' (al-maciayya) and 'divine judgment' (al-dayyanniyya) as degrees of witnessing by the heart that precede the final stage of sulük. Although they only sporadically appear in his writings, his elaboration on both degrees shows that he did at one point consider them to hold some significance for his students. Because we have no way to recover the chronology of his oeuvre, it remains impossible to say whether his limited attention to them should be taken as an indication that their place in his teachings changed over time. It is useful to note that, since neither act of witnessing appears to have relied directly on the teachings of his shaykhs, they were most likely the product of his own insights into the discipline of Sufism. So, for the sake of keeping our overview of his Sufi doctrine as comprehensive and accurate as possible, both will be briefly summarized here.

As for withness, in two separate treatises our Iraqi Sufi specifically mentions it as the final degree of witnessing by the heart from which the sālik may proceed to the most complete degree of the spirit. In both cases he states that it follows from establishing union between the attributes of divinity and lordship. ${ }^{90}$ When withness comes in sight on the basis of this union, the sälik is supposed to witness that God in His highness and aboveness over the Throne encompasses all creatures by His knowledge, hearing, sight, and nearness to them, as alluded to in the verse "He is with you wherever you are" [Q. 57:4]. ${ }^{91}$ This realization is portrayed by al-Wāsițī as follows:

89 For this distinction between the categories of divinity and lordship in the Qur'an, see for instance Ibn Taymiyya's; $M F$, vol. 2, pp. 408 \& 452; $M F$, vol. 10, p. 352; and especially his al-Furqān bayna awliyăa al-rahmān wa-awliy ă al-shayțān in $M F$, vol. 11, pp. 265-270, where he gives many examples of both categories. We have noted above that al-Wāsiṭi applies this distinction - though in a slightly different wording - in Miftāh al-márifa, p. 266, where he speaks of al-kalimāt al-taklīfyyāt and al-kalimāt al-takwìniyyāt in the Qur'an.

$90 \quad$ Al-Wāsițī, Miftāh al-márifa, p. 267; Madkhal ahl al-figh, p. 79 .

91 Al-Wāsițī, Risālatuhu ilā al-shaykh al-Maghribī, p. 111; 'Umdat al-țullāb, p. 205; Madkhal ahl al-figh, p. 79 . 
It is then, after having been desolate, that the servant reaches intimacy [with God] and becomes a companion (samir) for Him through the emanation of intimate knowledge of Him upon realizing the attribute of withness (min fayd márifatihi hina tahaqqaqa bi-sifat al-maciyya). Thus, he will not see between himself and his Lord any remoteness that veils him. Through spiritual taste and ecstasy - and not by eyesight or intellectual knowledge - he will find that [God] encompasses him and holds him by the forelock, and that He sees the darkest corners of his innermost secret: He is with him wherever he is! ${ }^{92}$

As for witnessing divine judgment, al-Wāsițī defines it as becoming unveiled to God's attribute of judgment (șifat al-dayyān) as it will manifest in the Afterlife when mankind is resurrected for the reckoning (hisāb). ${ }^{93}$ Like the witnessing of withness, we find that it is elaborated upon in two treatises only, both of which mention it specifically after the degrees of divinity and lordship. In one of these he imagines how God may manifest Himself to the sālik by this attribute in the Qur'an:

"I am God, there is no deity but Me" [Q. 20:14], the One Who gathers [all] people "for a Day about which there is no doubt" [Q. 3:25], when I'll dispense "each soul for that it has earned" [Q. 40:17], and I will not wrong "so much as the smallest speck; and if it be a good deed He will double it" [Q. 4:40]; and "whosoever does evil shall be recompensed for it" [Q. 4:4O], and I "shall set up the just balances for the Resurrection Day, so that not one soul shall be wronged anything!" [Q. 21:47]!94

When intimate knowledge (ma'rifa) of this attribute becomes such that it is constantly witnessed, al-Wāsiți holds that this should motivate the sālik to perform good works and subdue himself from transgressing God's restrictions out of fear for the horrors that will be seen on Judgment Day. Fear ought to be balanced by hope, he says, for the intimacy and love that God will grant His loyal servants on that day. Well aware that this resembles his advice to reflect on God's promise and threat for the witnessing of divinity, al-Wāsiți notes that this

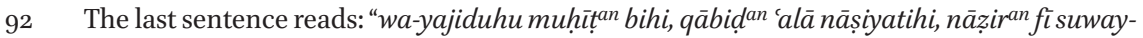
dā’ sirrihi - dhawq ${ }^{a n}$ wa-wajd ${ }^{a n}$ lā nazararan wa-ilm ${ }^{a n}$ - huwa ma'ahu haythu mā kāna." Cf. al-Wāsițī, Miftāh al-márifa, p. 267.

93 Al-Wāsiṭ̂, Qā'ida fì mazāhir al-shuhūd, p. 143.

94 Ibid. pp. 143-144. 
particular form of fear and hope belongs exclusively to the witnessing of divine judgment. ${ }^{95}$

The Spirit's Witnessing of Union (al-Jam') and Singularity (al-Fardāniyya)

As any travel plan, al-Wāsițîs directions through all the stages we have thus far described are given for the sole purpose to guide unto the destination of the journey that sulük represents. This is the overarching purpose of his entire oeuvre. For him, this destination is reached in the degree of witnessing that he sometimes designates by the term 'union' (jam) and sometimes by the term 'singularity' (fardāniyya), both of which are clearly meant to refer to one and the same experience. As we have found him do several times before, he describes a tajalli that conveys how he imagines God may manifest Himself to the one who reaches this final degree:

"I am God, there is no deity but Me" [Q. 20:14], the Master of majesty and glory, singular in singularity (fardāniyya), one in oneness (wahdaniyya), Who encompasses all the attributes of perfection and beauty (al-jāmic lijamīi șifät al-kamāl wa-al-jamāl). I am the greatest Lover, Who through the similitude of these attributes draws near unto those who love Me, who are subject to rapture from Me and burn with desire for Me. I disclose My beauty (jamālī and majesty (jalālī) to them so that their innermost secrets (asrār) become filled with their traces (āthār) and their spirits (arwāh $)$ expanded due to the rays of their lights! ${ }^{96}$

In line with the previous tajalliyyāt we have quoted, we will once more find that al-Wāsiți clearly chose his words carefully, and effectively described what are, in his view, some of the core elements of the final degree of witnessing.

Except for one treatise, al-Wāsițī consistently states that the final mashhad is usually preceded by annihilation $\left(f a n \bar{a}^{\prime}\right) \cdot{ }^{97}$ On two occasions he defines $f a n \vec{a}^{\prime}$ as the Sufi's "self-effacement from being aware of his own existence due to the

95 Ibid. pp. 143-145; Qāंida fì al-șifät, p. 322.

96 Al-Wāsițī, Qā'ida fı̀ maz̄ăhir al-shuhūd, p. 146.

97 In the following titles al-Wāsițī either directly or implicitly states that fana $\bar{a}^{3}$ precedes the witnessing of fardāniyyaljam': 'Umdat al-țullāb, p. 212; Miftāh al-ma'rifa, pp. 267-268; Qāंida fì mazāhir al-shuhūd, p. 145; Qā'ida min 'alāmāt al-tahaqquq bi-al-qayyūmiyya,

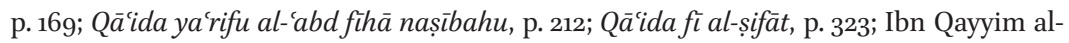
Jawziyya, Shifā’ al-'alīl, p. 16, quoted from al-Wāsiți’s Sharh Manāzil al-sā̉irīn. The only exception is in Madkhal ahl al-figh, p. 79, where he states that: "During [the witnessing of $j a m$ ] one is endowed with annihilation $\left(f a n \vec{a}^{\prime}\right)$ followed by subsistence $\left(\right.$ baq $\left.\vec{a}^{\prime}\right)$, then with intoxication $(s u k r)$ followed by sobriety (șậw)." 
severity of his absorption in [God's] Presence." ${ }^{\text {98 }}$ While he himself never labels it as such, this would be what Ibn Taymiyya calls "annihilation in the unity of lordship" (fanā’ fì tawhìd al-rubūbiyya). ${ }^{99} \mathrm{Al}-W a \bar{s}$ iți is not exactly clear in that regard, but it seems from his writings that what he defines as losing awareness of one's existence may indeed ensue from witnessing lordship. As we have seen above, he taught that practicing servitude of lordship should establish a spiritual connection with God through which one's own human will unifies with the divine will, wherein it then becomes annihilated so that only the will of God remains. Whether this annihilation is intended by him as the one that comes before the final degree of witnessing is never explicitly stated. However, one does get the impression that this may be the case, since he does describe the utmost degree of rubübiyya as a state that is between annihilation (fan $\bar{a})$ and subsistence $\left(b a q \bar{a}^{3}\right)$, and that this "is the limit of the servant and his journey (sayrihi), after which remains reaching the Real $(\mathrm{T})$ through the pull of divine attraction $(j a d h b a)^{\prime \prime 100}$ - in other words, this is the last stage of sulük before reaching the final degree of witnessing. What exactly is meant by that will become clear below when we further elaborate on the way he characterizes the witnessing of fardāniyyaljam c. For now, it is important to know that, in his view, this particular stage is preceded by an experience of annihilation that appears to result from the spiritual connection with God, realized through the witnessing of lordship.

How this subsequently leads to the final degree of witnessing in al-Wāsițîs doctrine may best be illustrated on the basis of one of the rare instances where he attempts to describe this process as he envisioned it. In the quote that now follows, he refers to it as the witnessing of jam ' instead of fardāniyya, and he discusses it in relation to the realization of rubübiyya (referred to by its synonym qayyūmiyya):

As for an indication of the realization of jam, this is a subtle secret that may be mistaken for unification (al-ittiha $\bar{d}$ ) and be regarded as monism $(a l-w a h d a)$. However, this is not the case, for the Lord (ST) is Lord and the servant is servant, their existence being at variance with one another: One exists [in pre-eternity], the other is brought into existence. An

98 "ișțilām al-wājid 'an al-shu'ūr bi-wujūdihi li-quwwat istighrāqihi bi-mawjūdihi," cf. al-Wāsițī, 'Umdat al-țulläb, p. 212; The term is similarly defined by him in Sharh Manāzil al-sä̀irīn, cf. Ibn Qayyim al-Jawziyya, Shifä’' al-'alīl, p. 16.

99 See for instance Ibn Taymiyya's $M F$, vol. 2, p. 314; vol. 3, p. 116; and several times in Fașl fi qawlihi "fa-hajja Ādamu Mūsā", vol. 8, pp. 303-37o, and vol. 10, p. 516.

100 Al-Wāsițī, Qā'ida fì al-umūr allatì yanbaghī an takūn hamm al-sālik, p. 197. Note that he uses 'qayyümiyya' as a synonym for rubübiyya here. 
indication of realizing jam ' after having realized qayyumizy a is that in the latter realization the branch connects to its root, so that it becomes the root that disposes over it, employing it as it pleases in accordance with its command and law. [The branch] is thus connected to this particular attribute, that being the attribute of qayyummiyya. From there it subsequently ascends until the branch's connection with its root subsists without being limited to this attribute alone. It then connects with the reality that encompasses all the divine properties (al-haqīqa al-jāmía li-jamīi al$n u \bar{u} t)$. Now, here the branch is connected with the entirety rather than with the attribute that is specifically associated with qayyummiyya alone. It is then that [the servant] realizes [jam '], so that he may only see [God], being realized, bewildered, and immersed in Him - as if he is Him at first, but then, in the end, there is only He (ka-annahu nafsuhu awwal an thumma laysa illa huwa ākhiran)! This resembles monism and unification in some respects - but God forbid it is that, for it is a unification of attributes and qualities (ittihāa wasfi naw'ì), whereas [the monists] refer to the unification of being identical in essence (al-ittihād al-'aynī al-dhātī). The people of truth (ahl al-haqq) know that, in spite of the former unification, God is [always] separate from His creation and high above them on the Throne. But the reason for this unification of attributes and qualities is the attraction of love (jädhib al-mahabba), because it is through his love that the lover is drawn near to his Beloved - which is a spiritual proximity, not an essential one (qurban mánawiyy ${ }^{a n}$ lā dhātiyy ${ }^{a n}$ ), for that will only come to pass in the Afterlife. ${ }^{101}$

In this passage the allegory of the branch is, of course, the servant, and that of the root God. After the first couple of lines, al-Wāsiți reiterates what we have seen earlier, namely, that it is through the realization of rubübiyya that a spiritual connection with God is established. After that, however, he starts to discuss the notion of union, and here we can make two observations regarding the way he understood the final stage in Sufism. First, he essentially defines what he understands by jam', and second, he discloses how this is brought about. We will clarify both observations on the basis of his other writings.

To begin, we must draw attention to al-Wāsițīs concern that, as a technical Sufi term to describe a kind of connection between the servant and God, what he understands as jam could be, and in fact has been, misused by Sufis to

101 Al-Wāsițī, Qāंida fì al-farq bayna mushāhadat al-qayyūmiyya wa-al-tahaqquq bihā, pp. 264-265. 
espouse the doctrine of incarnation and monism. ${ }^{102}$ In one of his refutations against the Akbarian school he actually addresses their use of the term directly, saying that "... they maintain that the essence of union ('ayn al-jam) signifies witnessing the existence of the Realasbeingidentical with [created] existents."103 In the earlier-quoted passage he likewise addresses this issue by stating that, for the monists, this kind of union signifies the unification of being identical in essence, al-ittiḩâd al-'aynī al-dhātī. Of course, he felt obliged to distance himself from such an understanding of the term, which he does in the same passage by defining it instead as a unification of attributes and qualities, ittihād wasfi naw i. But what does that mean?

Simply put, in al-Wāsițīs view the witnessing of union is to be connected spiritually - not physically - with the entirety of God's names and attributes. When union is witnessed, he explains, "everything that was separated (almutafarriqa $\bar{t}$ ) and the previous degrees of witnessing of the heart become united for the servant."104 It results in what he explained in the above quote as becoming connected to the reality that encompasses all the divine properties (al-haqìq a al-jāmi'a li-jamīi al-nu'üt), a term for which we can find several variations in his writings. The most common variation he uses is ' $a l$-amr al-kulli,'105 which we have come across a few times in our study already, and which is sometimes written in full as 'al-amr al-kullìal-jāmi' li-jamī'al-asmā' wa-al-sifiāt,' the complete reality that encompasses all the names and attributes. ${ }^{106}$ Other variations are 'the complete meaning that encompasses all the meanings and constituents' (al-ma'nāa al-kullì al-jāmi' li-jamì al-ma'ānīwa-al-juz'iyyāt) ${ }^{107}$ and 'the complete knowledge that encompasses all the meanings of the names and attributes' (al-ma'rifa al-kulliyya al-jāmi'ali-jamī'ma'ānīal-asmā’wa-al-șifät). ${ }^{108}$

102 As will become implicitly clear below, for al-Wāsițī, the 'mashhad al-jam ${ }^{\circ}$ refers to what the Sufis call jam'al-jam' or 'ayn al-jam'. Note that, in the technical vocabulary of the Sufis, the 'jam ${ }^{\circ}$ on its own is generally used as a synonym for $\operatorname{fana}_{\bar{a}}$, which is not how al-Wāsițī uses it in most cases as we will see.

103 Al-Wāsițī, Lawāmi al-istirshād, p. 95.

104 Al-Wāsițī, Madkhal ahl al-figh, p. 79; he also alludes to this in Qā'ida fì așnāf al-tảalluh, p. 155, where he describes the mashhad of fardāniyya as follows: "For [God's] companion, all that is separated from the Muhammadan traveler on the roads [towards arrival] becomes united" (fajitama'at li-șāhibihial-mutafarriqātmin sā̉ir al-țuruq al-Muhammadī). Al-Wāsițī, Rịhla, p. 50; Miftāḥ al-márifa, pp. 254 \& 274; Qā'ida fì așnāf al-ta’alluh, pp. 150151; Qāंida fì al-umūr al-muwașșila, pp. 216, 222, 224; Qāंida fì márifat al-naqș, pp. 231 \& 237; Q̄ं ida fì tajrìd, p. 252.

106 Al-Wāsițī, Talqūh al-afhām, p. 162; Q̄àida fì ma'rifat al-naqș, p. 231.

107 Al-Wāsițī, Qā'ida ya'rifu al-'abd fíhā nașībahu, p. 212.

108 Al-Wāsițī, Madkhal ahl al-fiqh, p. 79 . 
For al-Wāsitịi, all these terms signify that the final degree of witnessing pertains to God's essence - 'al-dhāt al-jāmi' li-jamī' al-șifät al-kamāliyya' - because it is His essence that encompasses all His perfect attributes. ${ }^{109}$ It is therefore why he also calls it the witnessing of fardäniyya, since 'singularity' for him alludes to the loftiness (jalāl), beauty (jamāl), glory (ikrām), and magnificence ('azama) of God's pre-eternal essence. ${ }^{110}$ After all, he elucidates using the Shādhilī maxim "He was and there was nothing with Him," so none can lay claim to singularity but Him. ${ }^{111}$ It is also precisely because this particular degree of witnessing is connected to the divine essence that he sometimes labels the one who reaches it a 'servant of God' ('abd Alläh) - in other words, one who serves 'Allāh', the all-encompassing name (al-ism al-jämi') of God's essence, and the source of all other names and attributes. ${ }^{112}$ Acknowledging that all creatures are, of course, God's servants, he clarifies that someone who becomes a servant in the truest sense of the word is set apart from the rest by having ascended from constituent degrees of witnessing (al-mashāhid al-juz'iyya) to the one degree that encompasses them all. ${ }^{113}$

But how is this degree brought to fruition? Earlier in the current section we found al-Wāsițī stating that the limit of sulūk is between annihilation and subsistence, after which there only remains ' jadhba', the pull of divine attraction. Likewise, we found that the unification that occurs when witnessing jam / fardāniyya comes from something he called 'jädhib al-mahabba', the attraction of love. In using such terms, our Iraqi Sufi clearly draws on the distinction between sulük and jadhb, a notion taught amidst the early Shādhiliyya of which we have made note in chapter $2 .{ }^{114}$

As opposed to all the previous degrees, al-Wāsițī held that the final witnessing can only be brought about by the favor $(f a d l)$ of God. ${ }^{115}$ In terms of terminology, it cannot therefore be reached by means of sulük, that is, the sālik's own effort to seek God. Describing the sālik, he says:

109 Al-Wāsițī, Miftāḥ al-márifa, p. 268.

110 Al-Wāsițī, Qã̄ida fì mazāhir al-shuhūd, p. 145; Qāंida fì aṣnāf al-ta’alluh, p. 154; Qāंida fì al-tajrīd, p. 252; Talqüh al-afhām, 162; al-Sirr al-Mașūn, p. 64.

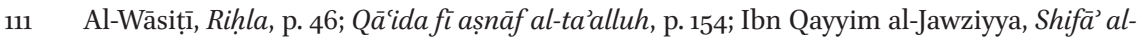
'alïl, p. 16, quoted from al-Wāsițīs Sharḥ Manāzil al-sāirìn.

112

Al-Wāsițī, Miftāh al-márifa, p. 269; Madkhal ahl al-figh, p. 80; Al-Wāsițī, Qā'ida ya'rifu al'abd fìhā nașibahu, p. 212.

113 Al-Wāsițī, Qā'ida ya'rifu al-'abd fihà nașībahu, p. 212.

114 This observation has also been made by Geoffroy, "Le traité de soufisme," p. 86.

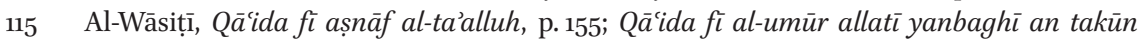
hamm al-sālik, p. 197; Q̄āida fì al-farq bayna al-ābid wa-al-mushāhid, p. 262; Madkhal ahl al-figh, p. 79 . 
There is [a great difference] between [the friend of God] and the lover who is [still] traveling unto God ('AJ) (al-muhibb al-sā̉ir ilā Allāh) by undergoing spiritual combat and struggles, taking himself to account, and guarding [his body parts]. [The latter] is restrained by these affairs, throwing himself into them heedlessly, thus traveling like someone who runs his face into thorns and rock. ${ }^{116}$

Although, al-Wāsiți admits, there are rare instances where God does choose a servant for nearness to Him by pulling him unto Himself without having first traversed the trajectory of $s u l \bar{u} k$, in most cases the previously described stages are required. ${ }^{117}$ In other words, it is principally after gradually progressing along the path, actively and persistently pursuing his destination, that God grants the sâlik a rank of friendship (wilāya) with Him:

The first sign of this is a pull of divine attraction (jadhba) that seizes his spirit (rüh). This causes him to ascend unto the [world of] dominion (almalaküt) until he is taken beyond it through his spirit's ascension. He is then appointed a rank in the proximity [of God] through the spirit's vision ('iyān al-rüh). This is what is called 'arrival' (wuṣull), and what [came before] was the witnessing of the hearts through the lights of faith. ${ }^{118}$

Thus, when the sălik is chosen to become a friend of God (walī), his spirit ascends unto the world of dominion ('âlam al-malaküt), from where it continues to be drawn near unto God. Al-Wāsiṭi never clearly defines what the world of dominion is, but indeed he understands it as a synonym for the world of the unseen ('âlam al-ghayb/al-ghuyūb), or the world of spirits ('ālam al-arwāhh), as

116 Al-Wāsițī, Talqūh al-afhām, p. 163.

117 Al-Wāsițī describes this in Umdat al-țullāb, p. 202, where he says: "There are people whose flower precedes the leaves of their tree. Such are those who are pulled by divine attraction (al-majdhübūn), who are overwhelmed by the glimmers and fundamentals of the divine realities in the beginning of the spiritual path (tazhuru 'alayhim lawäih wa-mabādi' al-haqā'iq fì awwal al-sulūk). As for the majority, their flower only becomes visible after completing the states of their tree by perfecting the states of knowledge and practice."

118 Al-Wāsițī, Miftăh al-márifa, p. 269. He describes the process of jadhb in a similar way in: al-Sirr al-mașūn, p. 65: "As the spirit flies, it enters the world of dominion ('âlam al-mala$k \bar{u} t)$ and encounters the pure unseen $(a l-g h u y \bar{u} b)$. When they [the majdhūbūn] reach this utmost degree, flying with their spirits unto the seats of truthfulness (maqāंid al-șidq) and the abodes of proximity (mawātin al-qurb), they become enraptured by love for the divine essence and are allotted the witnessing of singularity (mashhad al-fardāniyya)." 
opposed to the sensible, perceptible world of witnessing ('álam al-shahāda). ${ }^{119}$ When ascension has thus occurred, the titles of 'sālik' or 'sā'ir' no longer apply, and our Iraqi Sufi speaks instead of the majdhūb, someone whose spirit God has pulled unto Himself.

It is when the spirit has reached the utmost end in the world of the unseen that the final and most exalted degree of witnessing is perceived. Al-Wāsiți holds that all previous degrees perceived during the process of sulūk were but veils of light (hujub nürāniyya), because they were degrees of witnessing by the heart (mashāhid qalbiyya), "and the hearts cannot go beyond the divine attributes." 120 Only through divine attraction of the spirit can the union and singularity that pertains to God's essence be witnessed - which is why al-Wāsiți designates it as the one degree of witnessing that is of the spirit. ${ }^{121}$

He describes the actual witnessing itself as being annihilated from temporal existence (al-fanā' 'an al-wujūd al-mudmahill) while subsisting through God, the true reality of existence (al-baqāa bi-al-wujūd al-haqiquī). In spite of being annihilated, those who reach this station remain constantly in servitude in accordance with the revealed law, because God takes care of them by granting them a protected existence. ${ }^{122}$ As many Sufis had done before him, he bases this notion on the famous hadìth qudsī, according to which God said:

119 Al-Wāsițî, Qã̄ida fì bayān 'amal yawm wa-layla, p. 76; Qã̄ida fì i'tibār ahl al-khayr waghayrihim, p. 136; Qāंida fì dhikr al-karāmāt al-mu'ajjala, p. 285; al-Sirr al-mașūn, p. 65. Here, al-Wāsițī clearly relies on cosmological terminology commonly used by classical Sufis who distinguish between the álam al-mulk (the world of the kingdom, i.e. perceptible world) and the 'ālam al-malakūt; see for instance: al-Ghazālī, Ihyä’ vol. 1, p. 269. Such vocabulary was certainly also used among the early Shādhiliyya, as attested to by: al-Iskandarī, Ibn 'Ațā' Allāh (m. 709/1309) et la naissance, p. 185, and by the same author, Tartīb al-sulūk, p. 47 .

120 Al-Wāsițī, al-Sirr al-mașūn, p. 64; see also: Qã̄ida fì maz̧āhir al-shuhūd wa-al-márifa, p. 145 .

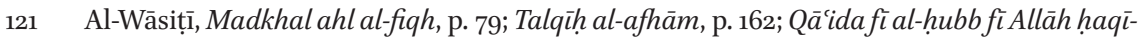

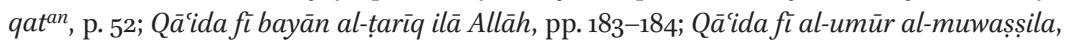
p. 224; Qã̄ida fì al-tajrìd, p. 252; Qāंida fi qawlihi ta'ālā "Inna Allāha ishtarā min almu'minin anfusahum wa-amwālahum bi-anna lahum al-janna", p. 293.

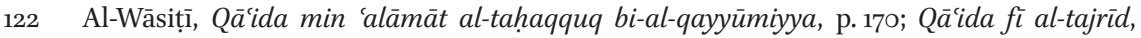
p. 253; Q̄̄ंida fì al-farq bayna al-ābid wa-al-mushāhid, p. 259; Madkhal ahl al-figh, p. 80; 'Umdat al-țullāb, p. 212; Ibn Qayyim al-Jawziyya, Shifä’’ al-'alül, p. 16, quoted from al-Wāsițìs Sharh Manāzil al-sāirìn; also alluded to in: Talqūh al-afhām, p.163. It is surely no coincidence that al-Wāsițī uses the verb ' $(y a)$ tawallă' when he speaks of God taking care of His servant; this is the same verb used in the Qur'anic verse "He [God] takes care of the righteous" (wa-huwa yatawallā al-șălihīn) [Q. 7:196], which was interpreted as a reference to the majdhüb in al-Iskandarìs Lațăif al-minan, p. 27, as noted in chapter 2. 
My servant continues to draw near to Me with supererogatory deeds (nawäfl) until I love him. When I love him, I will be his hearing with which he hears, his sight with which he sees, and his hand with which he strikes. If he asks Me [for something] I will surely give it to him, and if he seeks My refuge I will surely place him under My protection. ${ }^{123}$

To censure the Akbarian school once more, al-Wāsiți emphasizes that this is not in the sense that Creator and creature come to share one and the same existence, but rather that God's existence covers the servant's human existence, which consequently becomes like a phantom (khayāl) and a shadow $(z i l \bar{a} l) .{ }^{124}$ In a somewhat more poetic, metaphorical portrayal, he describes this experience as "the morning of divine unity (tawhid) that comes up from the horizon of the darkness of existence, which thence disappears little by little, like the night disappears from the light of dawn." 125 God should then make Himself known to His servant with knowledge of Him by Him (ma'rifatuhu bihi), which, al-Wāsițī says, "embodies everything that is made manifest of divine knowledge and the categories of [God's] names and properties - not by what the knower knows, but rather by what is known by the Known Himself as He is." ${ }^{26}$ In his understanding, this is what the Sufis call the 'station of subsistence' (maqām al-baqā'), 'the union of union' (jam' al-jam') - and its synonym 'the essence of union' ('ayn al-jam ) - or 'the second separation' (al-farq althānī). ${ }^{127}$

123 For the ḥadīth, see: al-Bukhārī, al-Jāmic al-musnad al-șaḥịh, vol. 8, p. 105. Al-Wāsițī quotes it in: Q̄ं ida fí bayān al-sulūk, pp. 157-158. He refers to it without quoting it word for word in: 'Umdat al-țullāb, p. 212; Miftāh al-márifa, p. 269; and: Ibn Qayyim al-Jawziyya, Shifä' al-'alīl, p. 16, quoted from al-Wāsițì's Sharh Manāzil al-sāirì̄n.

124 Al-Wāsițī, Qā'ida fì sulūk al-awliyā’, pp. 165-166, and: Qã̄ida min 'alāmāt al-tahaqquq bial-qayyūmiyya, pp. 169-170; Qā'ida fì al-farq bayna al-ābid wa-al-mushāhid, p. 26o; Qāंida fì al-farq bayna mushāhadat al-qayyūmiyya wa-al-tahaqquq bihā, p. 263.

125 Al-Wāsițī, Qāiida fì al-farq bayna mushāhadat al-qayyūmiyya, p. 263; a very similar wording is found in: Ibn Qayyim al-Jawziyya, Shifä' al-'alīl, p. 16, quoted from al-Wāsițīs Sharh Manāzil al-sāirìn.

126 "tandariju fì hādhihi al-ma'rifa jamīi mā abraza min al-ma'ārif wa-șunūf al-asmā’’ wa-alnu'ūt bi-mā ya lamu al-ma'rūf nafsuhu kamā huwa," cf. al-Wāsițīs Qã'ida fì bidāyāt alawliya $\bar{a}^{3}$, p. 176; for similar descriptions of this degree of márifa, see his Madkhal ahl alfiqh, p. 78; Qāंida fì mazāhir al-shuhūd, p. 145; Qā'ida fì al-farq bayna al-ābid wa-almushāhid, pp. 258-259.

127 For several references to $b a q \bar{a}^{\prime}$ in the context of the final degree of witnessing, see: alWāsițī, Qāंida fì mazāhir al-shuhūd, pp. 145-146; Qã̄ida fì al-farq bayna al-ābid wa-almushāhid, p. 260; 'Umdat al-țullāb, p. 212; Miftāh al-ma'rifa, p. 267; for him calling it 'ayn al-jam', see: Lawāmi' al-istirshād, p. 95; for him calling it jam' al-jam` and al-farq al-thānī, see: Q̄àida ya'rifu al-'abd fíhā nașībahu, p. 212. 
For this concept he relies heavily on what classical Junaydian doctrine says regarding the final stage of the Sufi path. While his choice to categorize it under the heading of jam'/fardāniyya may be rooted in later Sufi theory, and perhaps in part even his own creative thought, his description of the experiences during this stage of witnessing was undoubtedly based on the classical teachings of the Baghdad school of Sufism. What he describes is identical with what Éric Geoffroy has called the "double experience of fan $\bar{a}^{\prime} \mid b a q \bar{a}$," wherein the Sufi is "with God and with the world at the same time," which al-Junayd reportedly regarded as the very definition of Sufism. ${ }^{128}$ Al-Wāsițī would probably have been exposed to this concept among the Baghdadi Sufis already, and it was certainly taught amidst the early Shādhiliyya as well.

In conclusion to the topic at hand, we must make special note of the prominent role he allots to love in relation to the final degree of witnessing. ${ }^{129}$ Both the path towards it and the actual witnessing itself revolve around love. We have already seen that he held that the sălik's servitude of the divine names and attributes necessarily goes hand in hand with love for them; but it is also on account of this very servitude that God ultimately comes to love him back and decides to draw him unto Himself by divine attraction. After being chosen by God, the majdhüb, in turn, desires nothing but the nearness of his Beloved, which is depicted as "a whir in his chest that is like the whir of [a boiling] kettle, for his heart is boiling with love, reverence, thirst, and longing for the vision [of God] (al-'iyann)."130 It is then, with the spirit as its locus, that he acquires what al-Wāsiți calls 'distinguished love' (al-mahabba al-khạș̣a), which is love for the divine essence. It is said to flow forth from the station of subsistence that annihilates the servant from all that is not God, so that, in effect, his love for God becomes nothing other than God's love for him. ${ }^{131}$ Such is the state

128 Geoffroy, Introduction to Sufism, p. 15. For a good elaboration on the classical Sufi terms al-Wāsițī uses and how they all refer to the final station on the Sufi path, see for instance: Ali Hassan Abdel-Kader, The Life, Personality and Writings of al-Junayd: a Study of the Third/Ninth Century Mystic (London: Gibb Memorial Trust, 1976), p. 93; Michel Chodkiewicz, An Ocean Without Shore: Ibn 'Arabī, the Book, and the Law (Albany, NY: State University of New York Press, 1993), pp. 87-88; 'Alī b. 'Uthmān al-Hujwīrī, Revelation of the Mystery: (Kashf Al-Mahjúb), trans. Reynold Alleyne Nicholson (Accord, NY: Pir Press, 1999), p. 39 .

129 The importance of love in al-Wāsițī's writings has also been noted by Geoffroy, "Le traité de soufisme," pp. 86-87.

130 Al-Wāsițī, Talqūh al-afhām, p. 162.

131 On al-mahabba al-khāșṣa, see al-Wāsițī's 'Umdat al-țullāb, p. 212; al-Sirr al-mașūn, pp. 64-

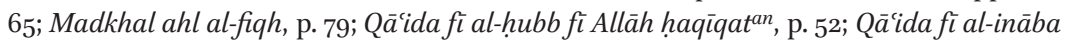
ilā Allāh ta'āla, p. 138; Qā'ida fì mazāhir al-shuhūd, p. 145; Qāंida min 'alāmāt al-tahaqquq bi-al-qayyūmiyya, pp. 169-170; Qāंida fì márifat al-naqș, pp. 231 \& 237; Q̄àida fì nafȳ̄ alkhawātir, pp. 246-247. 
al-Wāsițī describes as 'belovedness' (maḩbūbiyya) and 'intimate friendship' (khulla), which marks the true end of the spiritual journey. For as we observed at the beginning of the previous chapter, he essentially views the wali as someone who has become God's beloved (mahbüb) and intimate friend (khalīl). ${ }^{132}$

It is worth mentioning that while love is also allotted a central role by Ibn Taymiyya as the very foundation of the servant's relationship with God, his understanding of wilaya is in some respects quite different from that of alWāsiți. ${ }^{133}$ For the greater part this has to do with a completely different approach to terminology. For instance, our Iraqi Sufi occasionally calls those who become God's friends in the final degree 'the singular ones' (al-afräd) or 'the substitutes' (al-abdāl/budalä), titles for the awliy $\bar{a}$ ' that were quite common among the Sufis. ${ }^{134}$ I have not found Ibn Taymiyya ever mention the first term in this sense, and he problematizes such a use of the second term on several occasions. ${ }^{135}$ Instead, his doctrine on friendship with God relies solely on Qur'anic terms. In his view, all believers who abide by God's law are, strictly speaking, His $a w l i y \vec{a}$. However, he recognizes that the Qur'an distinguishes between two ranks: first, the rank of the common friends designated as 'the moderates' (al-muqtașidūn) or 'the companions of the right' (așhāa al-yamin), who perform all religious obligations; and second, the rank of the elite friends designated as 'the forerunners drawn near' (al-sābiqūn al-muqarrabūn), who in addition to the obligations also perform supererogatory acts of worship. ${ }^{136} \mathrm{Al}-$ though there are some parallels to be drawn here with al-Wāsițī, who also men-

132 Al-Wāsițî, Talqūh al-afhām, p. 163; Miftāh al-márifa, p. 269; Qā'ida fì bayān al-țarīq ilā

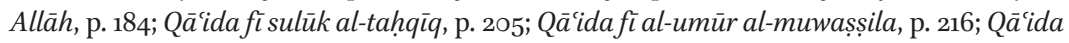
fì istijlāb al-widād fìmu'āmalat rabb al-arbāb, p. 276.

133 See for instance Ibn Taymiyya's al-Tuhfa al-irāqiyya, p. 373; and his al-Radd 'alä al-Shädhilī, p. 115, where he says: "Every friend of God (wali li-llāh) is a lover of God and beloved by God, because the servant's love for his Lord and the Lord's love for His servant are inseparable, for God only loves those who love Him." Love between God and man in Ibn Taymiyya's doctrine has been studied in: Bell, Love Theory, pp. 74-91.

134 For al-Wāsițī's mention of the afrād, see his: Lawāih min qawā'id ahl al-zaygh, p. 131; al-

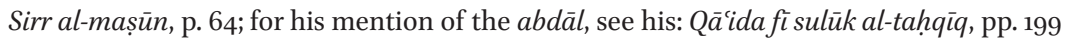
\& 204-205; Qã̄ida fì al-umūr al-muwașșila, p. 223; Lawāì min qawāid ahl al-zaygh, pp. 130-131.

135 See for instance Ibn Taymiyya's al-Furqān bayna awliyā' al-rahmmān wa-awliyă al-shayțān, MF, vol. 11, pp.167-168 \& 294; Minhāj al-sunna, vol. 1, pp. 93-94; Su’ila 'an al-hadìth almarwīfíal-abdāl, $M F$, vol. 11, pp. 433-444.

${ }_{136}$ Ibn Taymiyya takes these terms from the Qur'an, with the sābiqūn muqarrabūn being referred to in Q. 56:10-11 \& 88, Q. 35:32, and Q. 83:18 \& 21, and the așhāb al-yamin/ muqtașidūn in Q.56:8 \& 90-91 and Q. 35:32. Mention of this interpretation of the concept of wilāya is scattered throughout his writings. See for instance: al-Tuhfa al-irāqiyya, pp. 29o-291; al-Istiqāma, vol. 2, p. 41; Haqīqat madhhab al-ittihādiyyīn, $M F$, vol. 2, p. 224; Sharh futūḥ al-ghayb, $M F$, vol. 10, p. 463 . 
tions the term 'al-sābiqūn al-muqarrabūn' as a title for those who have attained God's friendship, it is very clear that this is never a reproduction of his shaykh's teachings on the subject. ${ }^{137}$ Conversely, Ibn Taymiyya, though acquainted with Sufi terminology, either refrains from using the terms we find in al-Wāsiți’s works or simply interprets them in a different way. For instance, he never himself adopts any variation of the term ' jadhba,' even though he was clearly aware of its existence as a Sufi concept within the subject of wilāya. ${ }^{138}$ Most striking is perhaps his (re)interpretation of the double experience of $\operatorname{fan} \vec{a}^{\prime} / b a q \bar{a}^{3}$, which is unmistakably different from the Junaydian definition al-Wāsițī adheres to. In his most basic phrasing, he defines it as: "annihilation from the worship of all that is other [than God] combined with subsistence in the worship of Him (T)." ${ }^{139}$ Much more can be said about his understanding of these terms, and this has been done by several scholars already. ${ }^{140}$ For the topic at hand it suffices to know that al-Wāsiți and Ibn Taymiyya clearly differed in their elaboration on several key Sufi terms. Finally, while we have recognized that Ibn Taymiyya does discuss the degrees of witnessing God's divinity and lordship, he never once speaks of the witnessing of union or singularity. We may therefore confidently conclude that al-Wāsițī in no way appropriated aspects of Ibn Taymiyya's teachings for his elaboration on the final stage on the Sufi path.

\section{Conclusion}

In this chapter we studied how al-Wāsiți built a sequence of degrees of witnessing on the basis of ma'rifa of God as extracted from the revealed texts. We had already observed in the previous chapter that this rests on becoming closely acquainted with all of God's names and attributes mentioned therein.

137 For al-Wāsițî̀s mention of the sābiqūn muqarrabūn, see his: Risāla fü ithbāt, p. 50; al-Sirr al-mașūn, p. 64.

${ }_{13} 8$ Ibn Taymiyya uses the root letters ' $\mathrm{j}$-dh-b' in Fașl fì al-șirāt al-mustaqìm fì al-zuhd wa-al-ibāda wa-al-wara', MF, vol. 10, pp.6oo-6o9, though never in the way al-Wāsițī understands the concept of jadhba. That Ibn Taymiyya was aware of its use among the Sufis is evident from his al-Radd 'alā al-Shādhilī, pp. 115-116.

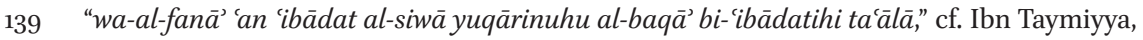
al-Radd 'alä al-Shädhilī, pp. 101-102; he repeats the same interpretation on p. 211, and it is also found in Faṣlfí qawlihi "fa-hajja Ādamu Mūsā", MF, vol. 8, p. 370.

140 See for instance: Thomas Michel, A Muslim Theologian's Response to Christianity: Ibn Taymiyya's Al-Jawab al-Sahih (Delmar, NY: Caravan Books, 1984), p. 33; James Pavlin, "Ibn Taymiyya's Theology," in Ibn Taymiyya: Epistle on Worship, trans. James Pavlin (Cambridge: Islamic Texts Society, 2015), pp. LXXXVI-XCI; Meier, "The Cleanest about Predestination," p. 325; Sarrio, "Spiritual anti-elitism," p. 287; Michot, "Ibn Taymiyya's Commentary," p. 132. 
We found that each divine name and attribute is connected to a specific human name or attribute through which it is served. This was based on the notion that the Sufi must realize the ultimate perfection and incomparability of God's names and attributes in view of the inherently imperfect nature of those of created beings. According to al-Wāsițī, this ultimately leads to the witnessing of these divine names and attributes, which is not a matter of perceiving their actual reality, since God's reality is completely separate from that of His creation. Rather, he explained it as perceiving the traces of their lights by means of the heart in the unseen (al-ghayb). These traces are to be recognized in the form of similitudes, as he held that it is through similitudes that created beings get to know God in their own terms. After this we examined the sequence of the most important degrees of witnessing he discusses in his writings, which are divinity, lordship/sustainment, withness, divine judgment, and finally, union/singularity. Throughout these steps we made note of instances where his teachings seem to have drawn from the shaykhs he studied under. This endeavor now allows us to make two important observations.

First, for his conception of witnessing he seems to have relied on the teachings of the Alexandrian Shādhiliyya and of his Damascene shaykh, Ibn Taymiyya. We found traces of Shādhili doctrine in several of the themes discussed, most notably in the practical application of ma'rifa through servitude of the divine names and attributes, but also in the notion of rejecting one's choice and self-direction, and the differentiation between sulük and jadhb. Taymiyyan doctrine was, above all, distinctly present in al-Wāsițīs understanding of the witnessing of divinity and lordship.

Second, unlike the subjects we studied in the previous chapter, we found that there are within al-Wāsitị̂s conception of the degrees of witnessing several teachings that markedly differ from, and at times even conflict with, Ibn Taymiyya's theological thought. For instance, the notion that a human being is composed of five dimensions - body, carnal soul, intellect, heart, and spirit all of which must be traversed consecutively in order to reach the end of the spiritual path, was clearly not acceptable to Ibn Taymiyya. Also, al-Wāsițîs entire elaboration on friendship with God as attained in the final degree of witnessing clearly diverges from that of his Hanbalī shaykh. Here, our Iraqi Sufi either has a different understanding of the relevant terminology, or uses terms not found in the works of Ibn Taymiyya.

This leads us to conclude that, although a follower of Ibn Taymiyya and an active member of his jamā'a, al-Wāsitịi had a voice of his own. His membership of the Taymiyyan circle did not mean that he was necessarily bound by the views of his teacher. The fact that he incorporated concepts from Shādhili doctrine into his Sufism shows that there was room for him to formulate his own 
views, which he based on the knowledge he acquired over the course of his travels - though we may add that he evidently put in effort to ensure these views were anchored in the framework of traditionalism. In the present chapter, this effort was, above all, visible in his definition of the witnessing of union, which was, in a sense, constructed around a rebuttal of the Akbarian school. By skillfully harmonizing traditional Sufi concepts, and Shādhilī and Taymiyyan teachings, our Iraqi Sufi provided his circle of pupils with an alternative form of tașawwuf that was in line with their traditionalist leanings. This Sufism was clearly not some replication of Ibn Taymiyya's views on Sufism, but rather stood on its own as an original synthesis of a centuries-old tradition. This conclusion supports the hypothesis set forth in chapter 3 that it was not Ibn Taymiyya but al-Wāsiți who fulfilled the role of Sufi master - or, shaykh al-sulük - for the members of their jamáca. 